\title{
DESENHO DE ALIMENTO EXTRUSADO PARA INTERVENÇÃO NUTRICIONAL À BASE DE MILHO (Zea mayz L.) E PULMÃO BOVINO
}

RAQUEL DE ANDRADE CARDOSO SANTIAGO

Tese apresentada na área de concentração de Nutrição da Faculdade de Saúde Pública da Universidade de São Paulo para obtenção do Grau de Doutor.

Área de concentração: Nutrição

ORIENTADOR: PROF DR JOSÉ ALFREDO GOMES ARÊAS

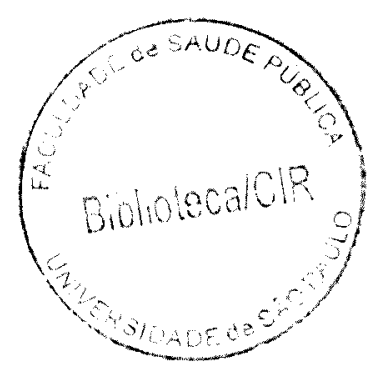


"Faça o importante, não o urgente."

Anônimo 
Esta tese é dedicada aos meus pais, Sônia e Antônio e, ao Fabrício, meu marido. 


\section{AGRADECIMENTOS}

Agradeço sinceramente ao Prof. José Alfredo Gomes Arêas por compartilhar todos esses anos de trabalho repletos de frustraçōes e sucessos.

Ao meu esposo pelo apoio infinito em toda essa trajetória.

$\dot{A}$ minha mãe, que me aconselhou em muitos momentos e me escutou horas a fio, mesmo a muitos quilômetros de distância.

A minha família que mesmo distante me deu tanto carinho e apoio durante esses anos.

$\grave{A}$ todos os amigos... mesmo estando afastada de muitos deles, todos sabem sua parcela de participação nesta fase da minha vida.

Às minhas amigas e colegas de laboratóno: Carol Conti, Déa, Rosana, Vanessa, Betina, Raquel, Rosa Nilda, Clarice, Carol Muron, Thais e Viviane por compartilharem muitos momentos desta formação. E àquelas que já não estão no grupo, Andréa Arikawa, Natali, Carla.

Aos Josés, Bezerra, Pereira e Baubino, que me socorreram e auxiliaram em muitos momentos.

Aos funcionários do Departamento de Nutriçāo.

Aos funcionários da Inbramaq, pela forma que me receberam e pelo apoio dado na produção dos snacks. Agradeço, especialmente à Sandra, ao Arruda, ao "Mala", ao Edimilson, ao Sr Francisco Crespo e ao Sr Mauro.

Ao Departamento de Nutrição da Faculdade de Saúde Pública - USP.

Ao CNPq pela bolsa concedida. 


\section{RESUMO}

Cardoso-Santiago RA. Desenho de alimento extrusado para intervenção nutricional à base de milho (Zea mayz L.) e pulmão bovino. São Paulo; 2002 [Tese de Doutorado - Faculdade de Saúde Pública da USP].

A produção de alimentos de conveniência, prontos para o consumo, tem aumentado consideravelmente no últimos anos. Muitos desses alimentos de conveniência são obtidos por extrusão termoplástica. A extrusão consiste na compressão de matérias-primas (geralmente farelo de milho com $12-15 \%$ de umidade) sob altas temperaturas e trabalho mecânico, fazendo com que o material se funda e expanda após rápida evaporação da água presente. Esses produtos, os snacks, apresentam alta aceitabilidade por suas características sensoriais, porém possuem valor nutritivo baixo, uma vez que sua composição em proteínas apresenta pequena quantidade $(4-7 \%)$ e baixa qualidade biológica $(\mathrm{VB}<50 \%)$, além do alto teor de gordura saturada (22-25\% adicionados durante a aromatização), apresentando ainda ferro em pequena quantidade e de baixa biodisponibilidade. Entretanto, eles parecem ser um importante componente da dieta, principalmente de crianças e adolescentes, o que acarreta um aumento do risco a determinadas deficiências e doenças. No Brasil, a anemia tem sido motivo de grande preocupação, devido a sua alta prevalência nessa faixa etária. Trabalhos anteriores revelaram que esses riscos poderiam ser diminuídos pelo uso de matérias primas alternativas, como o pulmão bovino, que é subutilizado, apesar de possuir proteína de alto valor biológico e ferro de alta biodisponibilidade. Desta forma, o trabalho propós a produção de snacks de milho e pulmão bovino (90:10). Para otimização do processo empregando-se apenas milho, foi utilizado a Metodologia de Superficie de Resposta, com a melhor resposta de textura em $11 \%$ de umidade, $170^{\circ} \mathrm{C}$ de temperatura e $104 \mathrm{rpm}$ de rotação da rosca $\left(R^{2}>0,85\right)$. Os produtos de milho com pulmão bovino, nas condições ótimas para textura, demonstraram ser altamente 
nutritivos sendo capazes de fornecer ferro de alta biodisponibilidade (25-15\% do RDA, 1989) para crianças e adolescentes, além de melhorar a qualidade protéica do produto. A aceitabilidade, medida em crianças e adolescentes entre 6 e 15 anos, foi bastante elevada (89\%), conseguindo assim, aliar praticidade à alta aceitabilidade e melhora na qualidade nutritiva dos produtos obtidos. 


\section{SUMMARY}

Cardoso-Santiago RA. Desenho de alimento extrusado para intervenção nutricional à base de milho (Zea mayz L.) e pulmão bovino [Design of an extruded product based on corn (Zea mayz L.) and bovine lung for nutritional interventions]. São Paulo (BR); 2002 [PhD Thesis - Faculdade de Saúde Pública da Universidade de São Paulo Brazil].

During the last years, production of snacks has been one of the fastest growing segments of the cereal foods industry. The most usual technology to obtain these products is extrusion cooking. This process is based on high heat and high-pressure that melts the raw material (generally corn gritz with $12-15 \%$ of moisture) and forces it through a die, where the water present in the melt flashes off - which puffs and expands the product. These are highly acceptable ready-to-eat snacks but after flavoring tend to be high in calorie and fat (22-25\%) and low in protein (4-7\%) and iron. However, these convenience foods can be a good way to convey some nutrient to specific population goups. Anaemia is an important health problem in Brazilian children and adolescents and could be reduced using unconventional raw materials to produce these popular foods. Bovine lung, which is a good source of iron and proteins was added to com to produce ready-to-eat snacks. The corn snack obtained by Response Surface Methodology, has the best texture at $11 \%$ of moisture, $170^{\circ} \mathrm{C}$ of temperature and $104 \mathrm{rpm}$ of screw rotation $\left(R^{2}>0.85\right)$. The enriched product obtained by the mixture of com and bovine lung (90:10) show high potential in terms of acceptability (89\%), high iron content (25-15\% of RDA) for children and adolescents that make them attractive as nutritional supplement for infants. 


\section{Sumário}

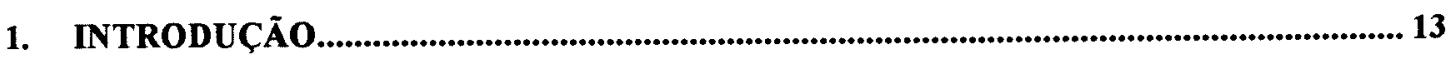

1.1. FERRO

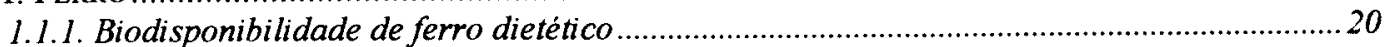

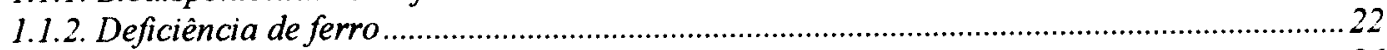

1.1.2.1 Anemia ferropriva

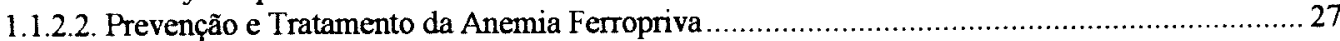

1.2. DESENVOL VIMENTO DE NOVOS PRODUTOS ENRIQUECIDOS EM FERRO …............................... 31

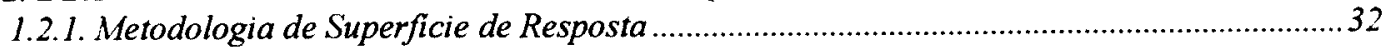

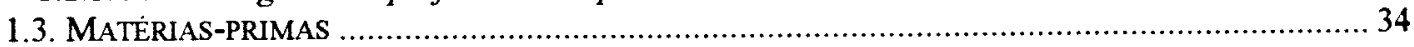

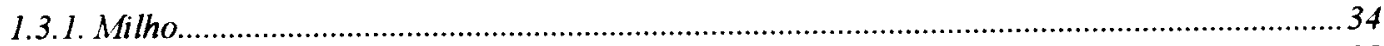

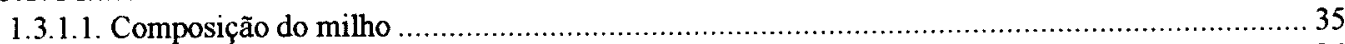

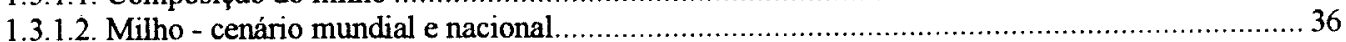

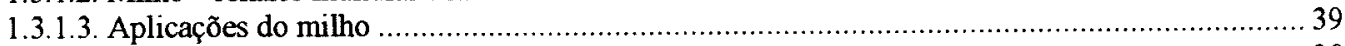

1.3.2. Pulmão bovino

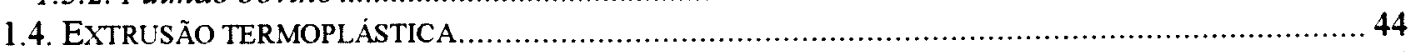

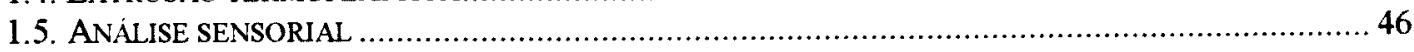

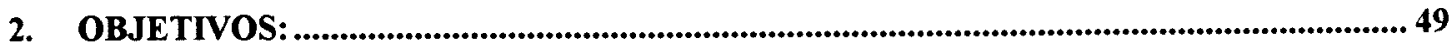

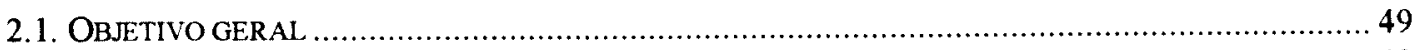

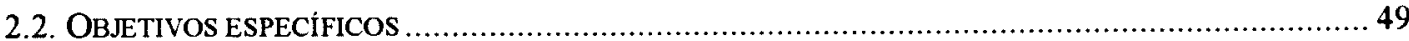

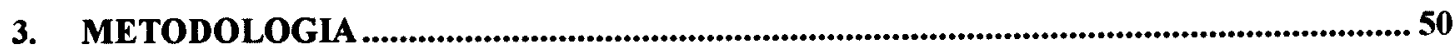

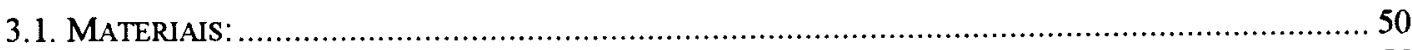

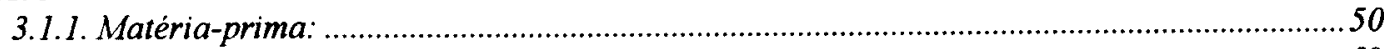

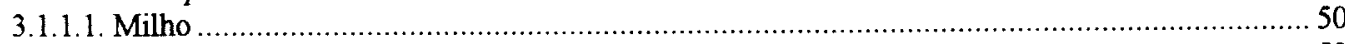

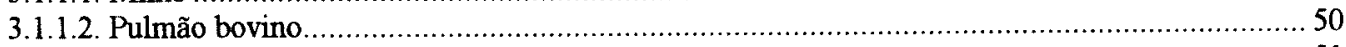

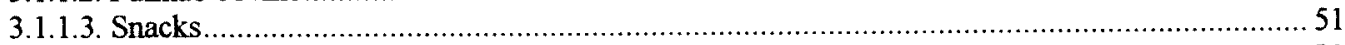

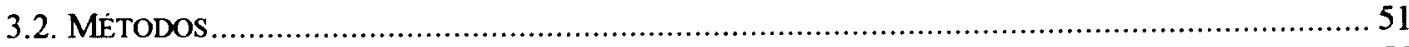

3.2.1. Análises químicas:

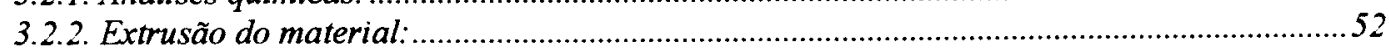

3.2.4 Metodologia de Superficie de Resposta (MSR) .....................................................................5

3.2.3.1. Otimização da condiç̧̃es de extrusão............................................................................5 54

3.2.4. Avaliação mecânica dos extrusados ..............................................................................5

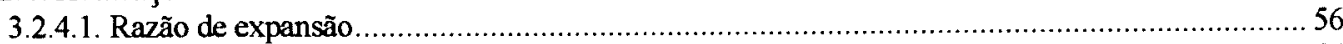

3.2.4.2. Força para cisalhamento completo ........................................................................... 56

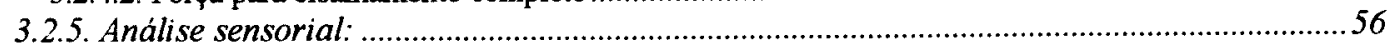

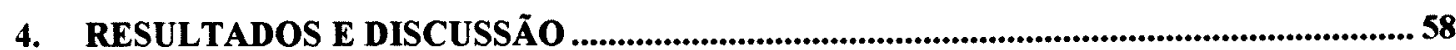

4.1. COMPOSIÇÃO CENTESIMAL

4.2. OTIMIZAÇÃo DA EXTRUSÃo Do SNACK DE MILLHO PARA RAZÃo DE EXPANSÃo ........................6

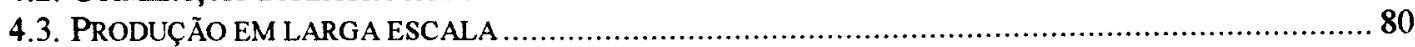

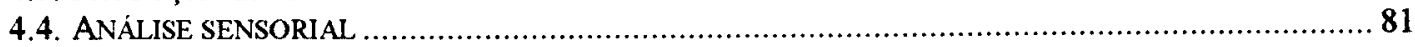

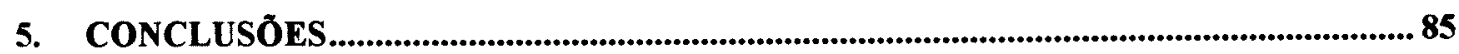

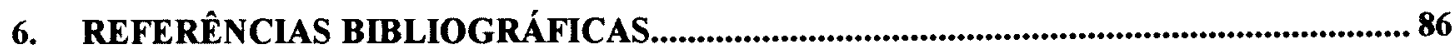

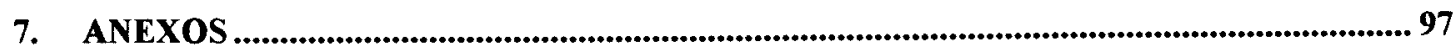




\section{LISTA DE TABELAS}

Tabela 1: Composição centesimal $(\mathrm{g} / 100 \mathrm{~g})$ e de ferro total $(\mathrm{mg} / 100 \mathrm{~g})$ do milho e pulmão bovino e dos extrusados de milho e do milho/pulmão bovino em base seca.

Tabela 2: Delineamento experimental $\left(E_{1}\right)$ e razão de expansão obtidos em função da umidade da amostra, temperatura de extrusão e rotação da rosca.

Tabela 3: Análise de regressão múltipla para o modelo de Segunda ordem da variável razão de expansão $(Y)\left(E_{1}\right)$

Tabela 4: Análise de variância para razão de expansão $\left(E_{1}\right)$

Tabela 5: Delineamento experimental $\left(E_{2}\right)$ e razão de expansão obtidos em função da umidade da amostra e temperatura de extrusão.

Tabela 6: Análise de regressão múltipla para o modelo de Segunda ordem da variável razão de expansão $(Y)\left(E_{2}\right)$

Tabela 7: Análise de variância para razão de expansão $\left(E_{2}\right)$

Tabela 8: Delineamento experimental $\left(E_{3}\right)$ e razão de expansão obtidos em função da umidade da amostra e temperatura de extrusão.

Tabela 9: Análise de regressão múltipla para o modelo de Segunda ordem da variável razão de expansão $(Y)\left(E_{3}\right)$

Tabela 10: Análise de variância para razão de expansão $\left(E_{3}\right)$

Tabela 11: Valores de umidade, rotação da rosca, temperatura e razão de expansão de gritz de milho. 
Tabela 12: Delineamento experimental $\left(E_{6}\right)$ e razão de expansão obtidos em função da umidade da amostra, temperatura de extrusão e rotação da rosca.

Tabela 13: Análise de regressão múltipla para o modelo de Segunda ordem da variável razão de expansão $(Y)\left(E_{6}\right)$

Tabela 14: Análise de variância para razão de expansão $\left(E_{6}\right)$ 


\section{LISTA DE FIGURAS}

Figura 1: Fatores contribuintes para deficiência de ferro em crianças e mulheres

Figura 2: Valores limites indicadores de niveis anormais de ferro

Figura 3: Estratégias para prevenção e controle da deficiência de ferro

Figura 4: Componentes do grão de milho

Figura 5: Consumo de milho no Brasil por segmento (mil toneladas)

Figura 6: Evolução do consumo de milho no Brasil

Figura 7: Superfície de resposta do extrusado de milho para razão de expansão em função da umidade e temperatura $\left(E_{1}\right)$

Figura 8: Superficie de resposta do extrusado de milho para razão de expansão em função da umidade e temperatura $\left(E_{3}\right)$

Figura 9: Superfície de resposta do extrusado de milho para razão de expansão em função da umidade e temperatura $\left(E_{4}\right)$

Figura 10: Superfície de resposta do extrusado de milho para razão de expansão em função da umidade e temperatura $\left(E_{6}\right)$

Figura 11: Superficie de resposta do extrusado de milho para razão de expansão em função da umidade e rotação da rosca $\left(E_{6}\right)$

Figura 12: Superfície de resposta do extrusado de milho para razão de expansão em função da temperatura e rotação da rosca $\left(E_{6}\right)$ 
Figura 13: Distribuição (\%) das notas dadas aos salgadinhos de milho e mistura de milho e pulmão bovino.

Figura 14: Distribuição (\%) das notas dadas ao snack de milho e pulmão bovino segundo idade.

Figura 15: Distribuição (\%) das notas dadas ao snack de milho segundo idade. 


\section{INTRODUÇÃO}

A indústria de alimentos tem promovido grande melhoria na oferta e qualidade de seus produtos, através do desenvolvimento de novas fontes alimentares e criação de alimentos inovadores. Dentre os processos para elaboração de novos produtos, a extrusão tem sido largamente utilizada devido sua simplicidade tecnológica e o baixo custo (SMITH 1976).

A aplicação do princípio de extrusão data do fim do século XVIII, quando Joseph Bramat construiu um equipamento com a finalidade de manufaturar tubos de chumbo. Anos mais tarde, por volta de 1935, esta invenção foi adaptada para indústria de alimentos na produção de macarrão. Posteriormente, foi aplicada para a produção de cereais matinais, bem como para um grande número de novos produtos extrusados. Para tal, foram utilizadas misturas de cereais, leguminosas e subprodutos animais (CARDOSO-SANTIAGO e ARÉAS 2001; CHÁVEZJÁUREGUI et al 2000; ARÉAS 1992; KINSELLA 1978; ROSSEN e MILLER 1973).

Processo essencialmente HTST (High Temperature - Short Time), a extrusão tende a maximizar os efeitos benéficos do aquecimento melhorando a digestibilidade, destruindo microorganismos, inativando enzimas e substâncias tóxicas, além de minimizar efeitos considerados nocivos em algumas circunstâncias, como escurecimento, destruição de aminoácidos essenciais e formação de aromas desagradáveis (MERCIER 1993, HARPER 1978, SMITH 1976).

$\mathrm{Na}$ produção de "snacks", os componentes alimentares interferem na performance dos produtos. Matérias-primas com elevado teor de proteinas tendem a uma menor razão de expansão, enquanto o maior teor de polissacarídeos 
aumenta a razão de expansão. Existem ainda outros fatores que podem interferir neste parâmetro de avaliação dos extrusados, como o teor de umidade, a granulometria, o teor de lipideos, as condições de extrusão e o equipamento. Entretanto, em geral, a expansão é dependente das modificações ocorridas durante a gelatinização do amido em função do seu teor e composição, associados a umidade do material e temperatura de extrusão (POMERANZ 1987). Sendo assim, os cereais têm sido amplamente utilizados para a produção de extrusados, pois possuem alto teor de amido, que proporciona um produto pronto para o consumo bastante expandido e de boa aceitabilidade.

Dentre os cereais, o milho (Zea mays L) apresenta elevado potencial para extrusão devido sua alta capacidade de expansão. Cereal originado e domesticado na América, não existem relatos de sua existência no Velho Mundo, até sua introdução na Europa ao final do século XV. Planta de rápida expansão, é muito adaptável e versátil, podendo ser produzido em diversas regiões, possuindo resistência a pragas e um elevado rendimento, sendo um dos quatro mais importantes produtos agrícolas do mundo. Pertencente à familia das Graminae, a semente do milho é composta pelo envoltório, endosperma e gérmen. Possui teor de proteína variando entre $8-10 \%$, amido $70-80 \%$ e lipídeos $4-7 \%$. Sua proteína, entretanto, é de baixa qualidade, apresentando deficiência em aminoácidos essenciais como a lisina e o triptofano (POMERANZ 1987, BASTOS 1987, FAO 1954). Produzido mundialmente, possui três finalidades principais: alimento, forragem para pastagens e matéria-prima para diversos produtos industrializados (FAO 1954). Dentre os produtos industrializados, destacam-se a produção de cereais matinais e snacks, dada a alta capacidade de expansão do milho quando submetido ao processo de extrusão. 
O pulmão bovino é outra matéria-prima que pode ser utilizada na produção de snacks, pois, apesar de sua rejeição estética e sensorial por maior parte da população, é uma matéria-prima com capacidade de agregar nutrientes aos snacks comerciais (CARDOSO-SANTIAGO E AREAAS 2001, PINTO et al 1997). Adicionado às farinhas com elevada capacidade de expansão, como o milho, fornece um snack sensorialmente aceitável e com proteína de alto valor biológico e elevado conteúdo de ferro biodisponivel (CARDOSO-SANTIAGO et al 2001, PINTO et al 1997).

Apesar de ter um custo muito baixo e um volume de produção alto, o pulmão bovino geralmente é subutilizado pela indústria alimentícia sendo utilizado, na maioria das vezes, para produção de ração animal. No Brasil são abatidos em torno de quatro milhões e trezentas mil cabeças de bovinos por trimestre com um crescimento de aproximadamente $5 \%$ a cada trimestre (IBGE 2001). Considerando esse crescimento constante do abate de bovinos, ressalta-se a necessidade de melhorar o aproveitamento de todo animal e não apenas da carcaça. Mesmo acarretando num aumento do custo de produção dos snacks de milho, sua adição em pequena quantidade, aproximadamente $10 \%$, é capaz de fornecer $30 \%$ das necessidades diárias de ferro para crianças em idade pré-escolar se forem consumidos $30 \mathrm{~g}$ de snack (CARDOSO-SANTIAGO et al 2001, MOREIRA-ARAÚJO et al 2002).

Na produção de snacks, a utilização de métodos de otimização é muito comum. Dentre eles, a Metodologia de Superficie de Resposta (MSR) tem sido largamente empregada. Introduzida por Box na década de 50, a MSR consiste de uma combinação de técnicas estatísticas que permitem a construção de modelos empiricos para a verificação de um conjunto de variáveis independentes numa ou mais variáveis dependentes (resposta). Normalmente, são tratadas como variáveis 
independentes todas aquelas que podem ser manipuladas durante 0 processamento, tais como: umidade do material, temperatura do processamento, velocidade de rotação da rosca, velocidade de alimentação da extrusora, taxa de compressão da rosca, relação comprimento: diâmetro da rosca e diâmetro do orifício de saida. As variáveis dependentes são verificadas no produto, sendo as mais comuns: razão de expansão da amostra, força de cisalhamento total, elasticidade, coesividade, dureza e aceitabilidade (BARROS NETO et al 1995, BASTOS et al 1991, BOX E DRAPER 1987). Assim, a MSR pode ser aplicada para determinar condições ótimas de um sistema tomando-se uma ferramenta de grande valia para pesquisadores.

Desta forma, o desenvolvimento de novos alimentos para a melhoria da saúde da população, através do uso de matérias-primas alternativas, bem como o uso de técnicas que facilitem a obtenção de novos produtos, e a fortificação de alimentos tem se mostrado uma ação de grande sustentabilidade dentro de um contexto de soluções para o problema das deficiências de micronutrientes no Brasil e no mundo (NUTTI 2000). 
Sabe-se que organismos internacionais relacionados à saúde vêm, nas últimas décadas, alertando que problemas como a deficiência de ferro e a anemia ferropriva estão se tornando cada vez mais comuns, tanto nos países mais desenvolvidos quanto nos paises em desenvolvimento, afetando mais de um bilhão de pessoas. Destacam-se neste número principalmente mulheres em idade reprodutiva e crianças em idade pré-escolar. As taxas de anemia superam, muitas vezes, problemas como desnutrição e moléstias infecciosas, acarretando em prejuizo no desenvolvimento físico, neurológico e mental da criança. Seus sinais e sintomas nem sempre são muito específicos, ficando mascarados, assim, em um grande número de casos, enquadrando-se na chamada "Fome oculta" (UNICEF/UNUMHO/MI 1998). 


\subsection{Ferro}

Atualmente, o problema nutricional mais importante da população brasileira, com severas consequências econômicas e sociais é a anemia ferropriva que pode ser definida como resultado de um desequilibrio no balanço entre a quantidade de ferro biologicamente disponivel e a necessidade orgânica, sendo as crianças nos primeiros anos de vida, e as gestantes os grupos mais vulneráveis (SOUZA et al 1997).

Segundo estimativas, a deficiência de ferro acarreta um custo anual, para a economia brasileira, de US\$ 605 milhões em tratamentos, perda de produtividade, dias de trabalho e, de outros US\$ 2 bilhões com baixos rendimentos escolares. 0 combate a esta deficiência - promoção da alimentação saudável e orientação do consumidor para a diversificação de dieta a baixo custo, distribuição de suplementos na rede de saúde e fortificação de parte da produção brasileira das farinhas de trigo e milho - pode melhorar esta deficiência (LINS e SILVA 2000).

A fortificação de alimentos tem se mostrado uma importante ação para o controle da anemia por carência de ferro em todo o mundo e deve ser incentivada. Outra alternativa para melhorar o valor nutritivo das farinhas de milho e trigo utilizada pela população brasileira seria a incorporação de matérias-primas alternativas na produção de snacks.

Quando se trata de fortificação de alimentos com ferro, existe um consenso baseado na experiência de muitos países industrializados e mais recentemente em paises em desenvolvimento, de que alimentos de uso frequente (como farinha de milho e trigo) ou ainda condimentos (molho de soja, açúcar e sal) sejam fortificados com ferro. Acredita-se ainda que a fortificação de alimentos de uso frequente como 
trigo, milho e arroz não seriam suficientes para reduzir significativamente a deficiência de ferro em crianças em idade pré-escolar e escolar, sendo necessário a fortificação de alimentos específicos para esta faixa etária (NUTTI 2000, ZIEGLER e FOMON 1996).

O ferro é um dos elementos mais abundantes da crosta terrestre, mas não é captado facilmente pelos organismos vivos devido sua insolubilidade em água. Nestes organismos vivos, participa de processos vitais como o transporte de $\mathrm{O}_{2}$ dos pulmões para os tecidos, na reserva muscular de oxigênio, nos sistemas que intervém no metabolismo energético, nas sinteses de proteínas dos ácidos nucléicos e nas mitoses celulares (TABOADA 1983, WORWOOD 1996).

No corpo humano sua quantidade é, em média $4 \mathrm{~g}$, sendo cerca de $65 \%$ sob a forma de hemoglobina, $4 \%$ sob a forma de mioglobina, $1 \%$ sob a forma de diversos compostos heme, $0,1 \%$ sob a forma de transferrina e de 15 a $30 \%$ armazenados no fígado sob a forma de ferritina. Apesar dos niveis normais de ferro no organismo serem dificeis de estabelecer, pode-se conhecer os extremos da deficiência ou a sobrecarga de ferro. A regulação desses niveis é feita por algumas proteinas - transferrina e ferritina.

A excreção de ferro difere de acordo com o sexo, idade, estado nutricional e fisiológico dos indivíduos. Pessoas do sexo masculino excretam em média 0,6 mg/dia de ferro pelas fezes. Em mulheres antes da menopausa, a perda pode chegar a 1,6 mg/dia em período menstrual. Em crianças pode ocorrer uma perda gastrointestinal maior que em adultos. Estas caracteristicas podem desencadear modificações nas reservas de ferro que variam de $0,5 \mathrm{mg} /$ dia na deficiência, a 1,5 $\mathrm{mg} /$ dia nos individuos com sobrecarga. Existem ainda, outras situações que podem ocasionar um aumento da perda de ferro - como doação de sangue; infestações 
parasitárias; perdas mínimas devido a ingestão de alguns medicamentos como aspirina por exemplo; e perda por outros estados patogênicos (GUYTON 1888, WORWOOD 1996).

\subsubsection{Biodisponibilidade de ferro dietético}

A disponibilidade de ferro encontrado nos alimentos depende da natureza e quantidade de ferro presente nos alimentos (HALLBERG 1981). Existem dois tipos distintos de ferro - o ferro heme e o ferro não-heme. O primeiro derivado da hemoglobina e mioglobina, presente em carnes e produtos de sangue, e o segundo, encontrado em diferentes quantidades em alimentos de origem vegetal. Existe ainda o de origem exógena que é o ferro adicionado para fortificação de alimentos e finalmente o ferro contaminante o qual pode ser proveniente do solo, água, ou utensílios utilizados no preparo de alimentos (HALLBERG 1981, DEMAYER 1989, QUINTAES 2000)

O conteúdo total de ferro da dieta tem como fator fundamental a biodisponibilidade do ferro ingerido ou seja, a sua absorbabilidade. O quanto o ferro é absorvido pelo organismo varia consideravelmente e depende de uma série de fatores incluindo a forma quimica, o consumo durante a mesma refeição de fatores que aumentem ou diminuam a absorção, a saúde e as reservas de ferro do individuo (HALLBERG 1981).

O ferro não heme é absorvido de forma diferente do ferro heme. A absorção de ferro não heme pode sofrer interferências também dos componentes da dieta que são obtidos através da taxa liquida de absorção dos mesmos, bem como seus constituintes e suas interações. Dentre estes fatores temos o ácido ascórbico; carnes; taninos; fitatos, fosfatos e fibras; ovos; leite; oxalatos, succinato e cisteina (HALLBERG 1981). 
a ácido ascórbico aumenta a absorção do ferro não-heme, sendo que na sua forma cristalina ou nativa, o efeito é similar. Tratamentos térmicos podem destruir o ácido ascórbico e, consequentemente, seu efeito na absorção de ferro. Acredita-se ainda que seu efeito seria independente de outros promotores de absorção, entretanto, quando existem dois promotores eles têm seus efeitos diminuidos, o que não ocorre na presença de inibidores de absorção. O ácido ascórbico pode ainda previnir a formação de hidróxido férrico insolúvel, que ocorre em meio alcalino, além de participar na formação de complexos com ions férricos, mais solúveis, pois preservam sua solubilidade no intestino (HALLBERG 1981).

A came e o peixe possuem um efeito promotor relacionado à dose ingerida com mecanismo de ação a ser esclarecido. Sabe-se que o seu efeito promotor não é devido às proteínas e nem à composição em aminoácidos. Acredita-se que o conteúdo de nucleoproteinas possa ser o responsável, embora estudos demonstrem que diferentes concentrações de nucleoproteinas não interferem na absorção de ferro. Entretanto, o que vale ressaltar é que as carnes tem um efeito positivo tanto na absorção de ferro heme quanto não heme (HALLBERG 1981).

Os taninos estão associados à diminuição da absorção de ferro não-heme em alimentos, devido à formação de complexos de ferro com esses componentes. Fitatos, fosfatos e fibras possuem efeitos pouco conhecidos, mas sabe-se que ocorre uma complexação do ferro com esses componentes da dieta, acarretando a diminuição da biodisponibilidade.

Ovos, leite e oxalato diminuem a absorção, enquanto succinato e cisteina parecem exercer efeito promotor na absorção de ferro. 
ferro heme possui $20-30 \%$ de absorção direta e geralmente contribui com um quarto do ferro absorvido de uma dieta rica em carne sendo sua biodisponibilidade pouco afetada pelos componentes da dieta (DEMAEYER 1989; HALLBERG 1981).

Os componentes de ferro usados para fortificação variam consideravelmente quanto à biodisponibilidade. Componentes facilmente absorvidos como o sulfato ferroso, possuem o inconveniente de alterar a coloração dos alimentos a que são adicionados, além de possuir sabor metálico e de facilitar a rancificação. Outros componentes, por sua vez, geralmente apresentam-se sob a forma de complexos muito estáveis ou como componentes de baixa solubilidade no trato gastrintestinal. O ferro contaminante possui solubilidade muito baixa apesar de estudos apontarem que o uso diário de panelas de ferro contribui para o tratamento e prevenção de anemia ferropriva (QUINTAES 2000).

\subsubsection{Deficiência de ferro}

A deficiência de ferro é isoladamente a mais comum das deficiências nutricionais no mundo. A elevada incidência e o fato de ser de difícil recuperação com possibilidade de consequências irreversiveis fizeram com que a Organização Mundial de Saúde (OMS) estabelecesse como meta a eleminação dessa deficiência até o ano 2000 . Entretanto, estima-se que hoje, $80 \%$ da população mundial ou seja, acima de 5 bilhōes de pessoas sofram de deficiência de ferro. Os grupos mais vulneráveis a essa deficiência são lactentes, crianças e mulheres (NUTTI 2000 , LÖNNERDAL e DEWEY 1996). 
O ferro, no organismo, encontra-se distribuido em estoque, transporte e ferro hemoglobínico. A medida em que ocorre aumento do déficit de ferro corpóreo, estes compartimentos vão sendo afetados sequencialmente, com a mobilização dos estoques, seguido pela diminuição do transporte e finalmente redução nos niveis de hemoglobina (CHAUD e FREITAS 1994, COOK et al 1992). Desta forma, a deficiência de ferro pode ser classificada em três estágios (DALLMAN 1981 citado por SZARFARC et al 1995):

a. Depleção de ferro - ocorre uma diminuição da ferritina sérica (ferro armazenado), manutenção dos níveis de transferrina e concentração de hemoglobina.

b. Deficiência de ferro - diminuição da saturação de transferrina, com concentração de ferro plasmático baixa e concentração de hemoglobina normal.

c. Anemia ferropriva - diminuição da produção de hemoglobina com aumento da protoporfirina eritrocitária livre, caracterizando anemia hipocrômica e microcítica.

A deficiência de ferro, mesmo de forma moderada, está associada à prejuizos na capacidade produtiva, no desenvolvimento cognitivo e na imunocompetência (SZARFARC et al 1994, DALLMAN 1987, BAYNES E BOTHWELL 1990). Os principais sintomas dessa deficiência estão relacionados com o comprometimento do transporte de oxigênio para os tecidos, devido à diminuição da concentração de hemoglobina, podendo ocorrer, ainda, anormalidades bioquímico-fisiológicas atribuídas ao comprometimento de funções metabólicas em que o ferro atua como co-fator ou parte integrante de enzimas ou proteinas (CHAUD e FREITAS 1994, COOK et al 1992, SILMES et al 1980). 
Em crianças a deficiência de ferro é caracterizada por irritabilidade e demonstração de desinteresse, limitando o potencial intelectual de maneira significativa em crianças em desenvolvimento (SHEARD 1994, POLLIT et al 1986). São descritas ainda alterações metabólicas diversas, alterações de pele e mucosa e comprometimento do sistema digestivo e imunológico (SOUZA et al 1997). Em adolescentes alguns estudos (ANTILLA et al 1997; BRUNER et al 1996) demonstram atraso no desenvolvimento puberal associado ao decréscimo dos estoques desse mineral e melhor desempenho nos testes de memória e leitura verbal para meninas adolescentes suplementadas. Outro fator que interfere no crescimento pleno desta fase etária seria a presença de infecções, principalmente parasitárias, por interferirem nas reservas de macro e micronutrientes (ASSIS 2000)

A regulação da absorção e a reciclagem eficiente das reservas corporais de ferro são responsáveis pelo balanço desse mineral no organismo. Entretanto, quando a perda é maior que a sua absorção, tem início o processo da deficiência de ferro, a qual ocorre de forma gradual e progressiva, resultando na anemia (SZARFARC et al 1995). 
Figura 1: Fatores contribuintes para a deficiência de ferro em crianças e mulheres

\section{DEFICIEYCIA DF FERRO}

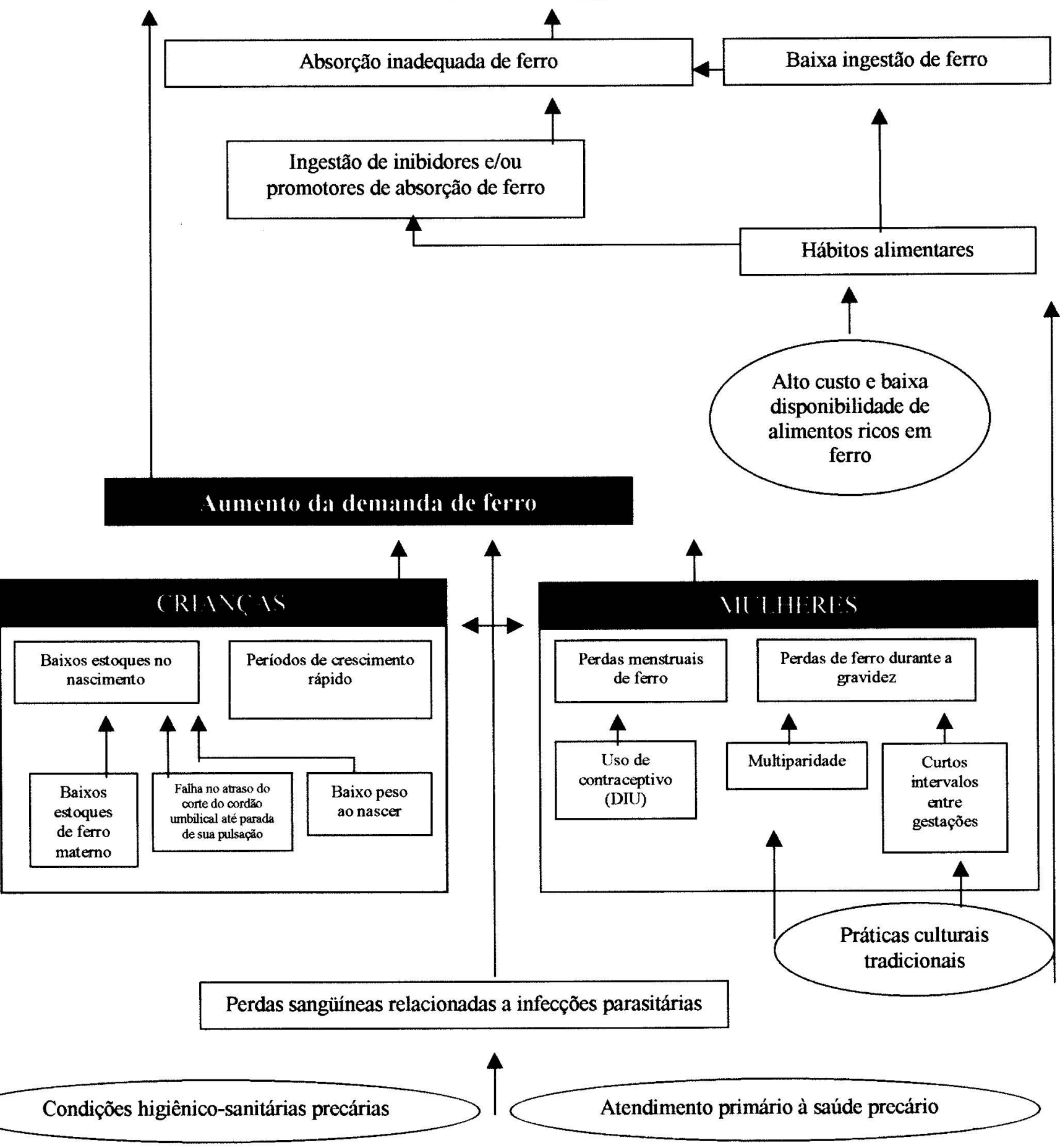

Fonte: Iron deficiency Programme Advisory Service (IDPAS); International Nutrition Foundation (INF) (UNICEF/UNUMHO/MI,1999) 


\subsubsection{Anemia ferropriva}

A anemia é a patologia de maior prevalência em todo o mundo, não só nos paises em desenvolvimento como também nos países mais desenvolvidos (TORRES et al 1995; CHAUD e FREITAS 1994; FAOIOMS, 1991; BAYNES e BOTHWELL 1990). A Organização Mundial da Saúde, define a anemia nutricional como um estado em que a hemoglobina sangüinea está em niveis muito baixos devido à carência de nutrientes como ferro, ác. fólico, vitamina $B_{12}$, cobre e vitaminas $A, C$ e E. Entretanto, a mais frequente é a resultante de uma grave deficiência de ferro, com a estimativa de 2 bilhões de pessoas anêmicas em todo mundo (NUTTI 2000; OMS 1968).

A deficiência de ferro tem como principal causa a biodisponibilidade do ferro alimentar, devendo o mesmo estar presente no organismo em quantidades suficientes para as funções metabólicas. Durante a infância, o principal componente da dieta é o leite, o que torna a ingestão nutricional de ferro baixa ou marginal na maioria dos paises em desenvolvimento. Lactentes alimentados ao seio normalmente não apresentam deficiência de ferro, uma vez que mesmo contendo quantidades relativamente pequenas deste mineral, a biodisponibilidade de ferro do leite humano é considerada maior do que no leite de vaca. Além disso, a duração das reservas de ferro ao nascer são um fator determinante no aparecimento da deficiência de ferro (LÖNNERDAL e DEWEY 1996; SOUZA et al 1997).

Entre o quarto e sexto mês de vida, as reservas de ferro acumuladas pelo feto se esgotam e a alimentação passa a exercer um papel fundamental no atendimento das necessidades deste nutriente. A partir desta fase, os alimentos que normalmente compōem a dieta são leite, frutas e verduras, que tem baixo teor de ferro e os cereais e leguminosas que fornecem quantidades moderadas e pouco 
biodisponiveis de ferro. A carne, que é uma boa fonte de ferro de alta biodisponibilidade, é pouco consumida em paises em desenvolvimento e constitui a menor parte da dieta promovendo uma ingestão inadequada do mineral e consequente elevação na prevalência de anemia (LÖNNERDAL e DEWEY 1996; SOUZA et al 1997).

A classificação da anemia é feita de forma arbitrária em: leve, moderada e severa. Na tentativa de quantificar esses valores, a Joint WHO/UNICEF Nutrition Support Programme estabeleceu como anemia leve, moderada e severa, concentrações de hemoglobina superiores a $80 \%$, entre $80 \%$ e $60 \%$, ou menor que $60 \%$ dos valores de corte respectivamente. Para o diagnóstico desta moléstia são utilizados os niveis de corte de $11 \mathrm{mg} / \mathrm{dl}$ para crianças de 6 meses a 5 anos e 12 mg/dl para crianças de 6 a 14 anos, segundo a Organização Mundial da Saúde (DeMAEYER, 1989).

\subsubsection{Prevenção e Tratamento da Anemia Ferropriva}

A prevenção de deficiência de ferro e anemia ferropriva se baseia em suplementação medicamentosa, associada ao aumento da ingestão de ferro dietético, controle de infecções e fortificação de alimentos com ferro (NUTTI, 2000). 
Figura 3: Estratégias para prevenção e controle da deficiêcia de ferro

\section{AVALIAÇÃO DA DEFICIÊCIA DE FERRO E ANEMIA FERROPRIVA}

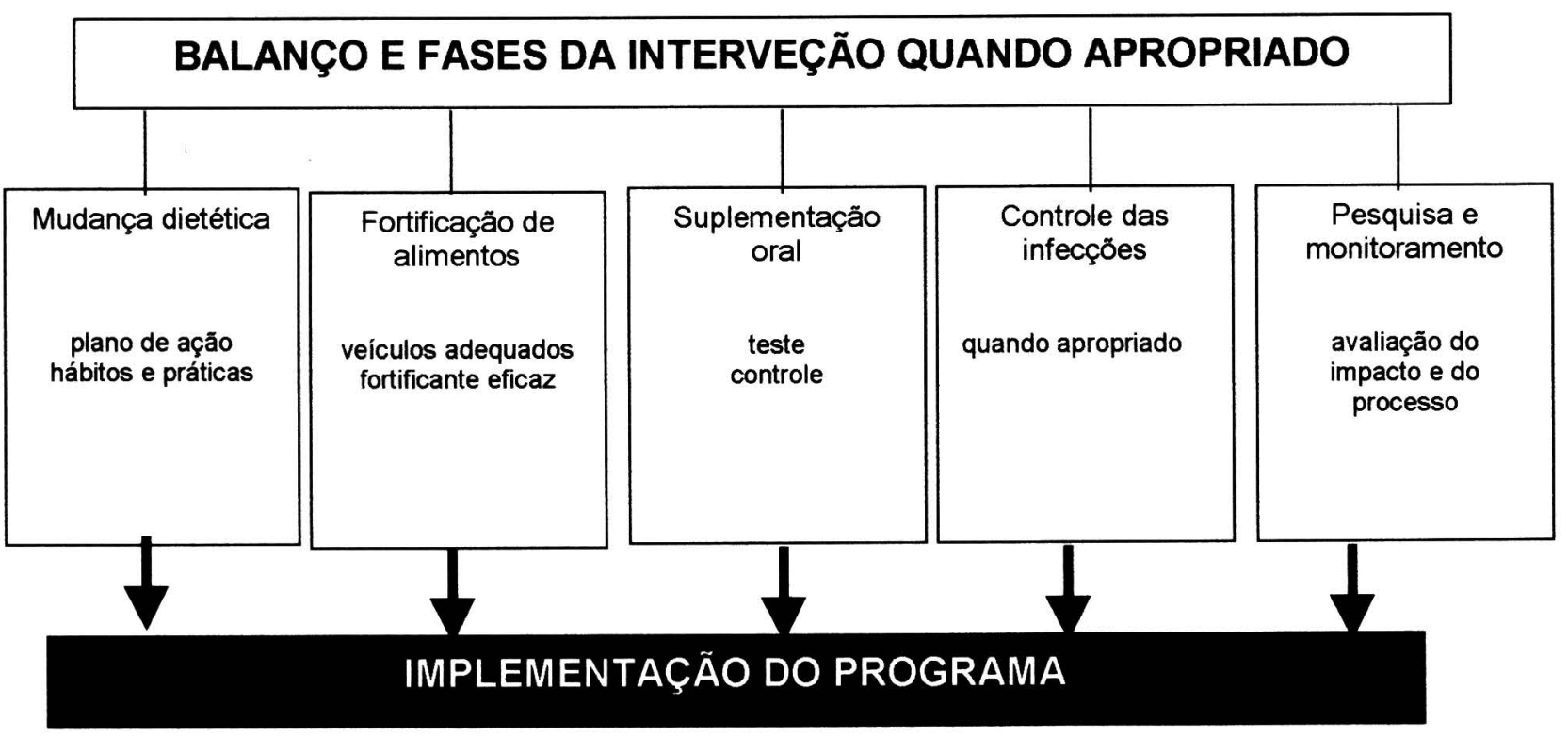

\begin{tabular}{|c|c|c|c|}
\hline \multicolumn{4}{|c|}{ PROGRAMAS ASSOCIADOS } \\
\hline $\begin{array}{c}\text { Planejamento } \\
\text { familiar } \\
\text { Saúde reprodutiva }\end{array}$ & $\begin{array}{l}\text { Promoção do } \\
\text { aleitamento materno }\end{array}$ & $\begin{array}{l}\text { Expansão de } \\
\text { programas de } \\
\text { imunização }\end{array}$ & $\begin{array}{c}\text { Gerenciamento } \\
\text { integrado de } \\
\text { doenças da infância }\end{array}$ \\
\hline
\end{tabular}

Fonte: UNACC/SCN Iron Working Group (UNICEF/UNUMHO/MI, 1999). 
Associado à prevenção faz-se necessário o combate à deficiência de ferro e à anemia já instalada. Para tal, a Organização Pan Americana de Saúde / Organização Mundial da Saúde (PAHONHO) propuseram para a América Latina uma série de intervenções com impacto a curto, médio e longo prazo. Estas intervenções incluem fortificação de alimentos largamente e frequentemente consumidos de baixo custo e que se encontrem disponiveis no mercado; suplementação medicamentosa com ferro em gestantes e crianças menores de dois anos; diversificação dietética; e monitoramento do impacto das intervenções através de estudos epidemiológicos (FREIRE 1997).

A viabilização da conduta proposta, pode ser obtida com a adoção de algumas práticas (VITERI 1997):

a. melhorar a prática dietética e estilo de vida através do aumento da ingestão e biodisponibilidade de ferro, além da ingestão adequada de outros nutrientes envolvidos na eritropoese, como a vitamina $A$, riboflavina, folato e vitamina $B_{12}$. Isso inclui aleitamento materno, variedade e quantidades adequadas de alimentos contendo ferro heme, além de alimentos com grande quantidade de ferro como as leguminosas e alguns vegetais combinados com alimentos promotores de absorção e evitar o consumo de alimentos ricos em inibidores da absorção de ferro durante as refeições. Adotar práticas culinárias que reduzam o fitato e outros polifosfatos tais como, tratamento térmico, fermentação e germinação. Finalmente, a higienização adequada dos alimentos e não menos importante, a prática de atividade física com o intuito de aumentar - gasto energético e consequentemente a ingestão alimentar, sem aumentar o risco de obesidade. 
b. fortificação de alimentos

c. cuidados pré-natal e neonatal, incluíndo a prevenção e controle da anemia gestacional obtido através da suplementação com ferro na segunda metade da gestação; prevenção de partos prematuros, hemorragias e infecções; amamentação ao seio; e, espaçamento adequado entre as gestações.

d. suplementação com ferro praticada principalmente em anemia gestacional e em crianças recém desmamadas até aproximadamente três anos de idade. Em crianças com baixo peso ao nascer, a suplementação é recomendada a partir de 2-3 meses de idade.

e. terapia com ferro indicada no tratamento de anemia.

f. controle de infecções e saneamento básico são fundamentais na contenção da deficiência de ferro pois auxiliam no controle de doenças parasitárias; infecções virais e bacterianas, bem como doenças bacteriais e virais crônicas, incuindo tuberculose e aids.

g. educação e informação em saúde e nutrição para a população e entidades governamentais.

Na prática clinica, individuos que tenham anemia ferropriva grave confirmada devem receber tratamento medicamentoso. 


\subsection{Desenvolvimento de novos produtos enriquecidos em ferro}

O sucesso no desenvolvimento de produtos enriquecidos está relacionado à sua qualidade. Dependendo do método usado em um processo de formulação, os novos produtos obtidos nem sempre serão de alta qualidade, pois muitas vezes há necessidade de descartar o produzido e reelaborar o produto através de novos testes acarretando custos muito elevados. De acordo com consultores na área de qualidade, $80 \%$ de todos os defeitos de qualidade ocorrem na fase de planejamento para elaboração do produto (BARROS NETO et al 1995, DZIEZAK 1990).

Uma das possibilidades para reduzir este problema seria adotar planejamentos experimentais antes do inicio da produção. Baseado nesse pressuposto, utilizando-se de técnicas estatísticas avançadas, o planejamento experimental è um projeto para estabelecer diversificações nas variáveis estudadas, a fim de verificar o seu efeito em alguns resultados especificos (BARROS NETO et al 1995, DZIEZAK 1990).

Realizado de forma sistemática ele capacita o estudo simultâneo de diversas variáveis, com a possibilidade de obtenção de vários dados à partir de um número reduzido de experimentos e baixo custo. Além disso, experimentos como estes permitem a predição de efeitos ocasionados pela modificação de variáveis consideradas criticas (BARROS NETO et al 1995).

Projetos experimentais como estes não são recentes. Eles datam da década de 20 com experimentos em agricultura e, anos mais tarde, passaram a ser utilizados pela indústria japonesa que melhorou e ampliou as técnicas iniciais, as quais foram retomadas pela indústria ocidental no inicio da década de 80 , como sendo uma técnica inovadora (DZIEZAK 1990). 
Comparado às técnicas tradicionais de otimização, nas quais apenas uma variável é alterada por vez, planejamentos experimentais oferecem várias vantagens. Primeiro, o custo/benefício no que diz respeito ao tempo e ao número de experimentos; segundo, a capacidade de obter valores ótimos; e finalmente, determinar o efeito não apenas das variáveis mas também de suas interações (OZDEMIR e DEVRES, 2000).

\subsubsection{Metodologia de Superficie de Resposta}

Dentre os métodos empregados para planejamentos experimentais, a Metodologia de Superficie de Resposta (MSR) é uma ferramenta de grande valia para pesquisadores devido sua capacidade de determinar condições de respostas ótimas para um sistema. Introduzida por Box na década de 50, a MSR é um processo para otimização que consiste de uma combinação de técnicas estatísticas que permitem a construção de modelos empíricos para a verificação de um conjunto de variáveis independentes numa ou mais variáveis dependentes. A MSR e sua análise são utilizadas para encontrar combinações de valores experimentais que irão gerar um modelo de respostas ótimas as quais podem ser máximas ou mínimas dependendo da sua natureza (GÁCULA e SINGH 1984; BARROS NETO et al 1995).

Normalmente são tratadas como variáveis independentes na extrusão de um alimento todas aquelas que podem ser manipuladas durante o processamento, tais como: umidade do material, temperatura do processamento, velocidade de rotação da rosca, velocidade de alimentação da extrusora, taxa de compressão da rosca, relação comprimento / diâmento da rosca e diâmetro do orifício de saida. As variáveis dependentes são aquelas verificadas no produto e que podem ser mensuradas sendo, em produtos extrusados, as mais comuns: razão de expansão 
da amostra, força de cisalhamento total, elasticidade, coesividade, dureza, aceitabilidade, etc (BARROS NETO et al 1995; BASTOS et al 1991; BOX e DRAPER 1987; AGUILERA e KOSIKOWSKI 1976).

Matematicamente, $y=f(x 1, x 2, \ldots \ldots . x n)+E$, onde $y$ refere-se à resposta observada ou seja à variável dependente; $f$ é a função da resposta $x 1, x 2, \ldots \ldots . . \times n$, os quais são variáveis quantitativas conhecidas como independentes e $E$ o erro aleatório. Ainda que $f$ seja desconhecido, pode ser adotado como primeira aproximação numa função linear ou quadrática.

Os estudos de otimização do processo de extrusão por MSR têm sido largamente empregados e buscam racionalizar as condições de extrusão para obter um produto final de boa qualidade e com capacidade de extrapolar seus resultados laboratoriais (escala piloto) para escala industrial (COLONNA et al 1989).

$\mathrm{Na}$ extrusão de materiais amiláceos o uso da MSR tem mostrado elevado potencial e tecnologia relativamente simples apesar de exigir um controle sistemático das variáveis estudadas. Tal fato se deve à complexidade na composição das matérias-primas, assim como no grande número de variáveis envolvidas (COLONNA et al 1989, El DASH et al 1984). Desta forma, os cereais tem sido amplamente utilizados para a produção de extrusados, devido seu alto teor de amido que proporciona um produto bastante expandido e de boa aceitabilidade.

Há um leque de matérias-primas para obtenção de produtos extrusados populares enriquecidos em ferro para o combate da anemia nutricional. 


\subsection{Matérias-primas}

\subsubsection{Milho}

O consumo do milho (Zea mays, L) por americanos data do ano 5 mil a.C.. Este cereal foi a alimentação básica de várias civilizações importantes ao longo dos séculos e povos como os Maias, Astecas e Incas reverenciavam o cereal na arte, na religião e grande parte de suas atividades diárias eram ligadas ao seu cultivo. Com a descoberta da América e as grandes navegações do século XVI, a cultura do milho se expandiu para outras partes do mundo. Cristóvão Colombo levou as primeiras sementes à Europa, e os portugueses as levaram até a Ásia. Hoje é cultivado e consumido em todos os continentes e sua produção só perde para a do trigo e do arroz (ABIMILHO 2001, BASTOS 1987, FAO 1954).

No Brasil, o cultivo do milho vem desde antes do descobrimento. Os índios, principalmente os guaranis, tinham o cereal como o principal ingrediente de sua dieta e, com a chegada dos portugueses, novos produtos à base de milho foram incorporados aos hábitos alimentares levando a um aumento no seu consumo pelos brasileiros (ABIMILHO, 2001).

A partir da segunda metade do século $X X$, o desenvolvimento de espécies hibridas aumentou sua produtividade e qualidade. Atualmente encontramos aproximadamente 150 espécies de milho, com grande diversidade de cor e formato dos grãos, sendo um cereal fácil de ser plantado e colhido, seja ele milho duro, doce ou de pipoca. No Brasil, é uma cultura que ocupa extensas áreas. Entre as principais regiōes produtoras estão o norte do Paraná, o Triângulo Mineiro, o oeste de São Paulo e o Vale do Taquari, no Rio Grande do Sul (ABIMILHO, 2001). 
Cultivado em todo país, possui grande versatilidade para o aproveitamento na alimentação humana, sendo a matéria-prima principal de vários pratos culinários como cuscuz, polenta, angu, bolos, canjicas, mingaus, cremes, entre outros. Ele pode ser consumido diretamente ou como componente para a fabricação de balas, biscoitos, pães, chocolates, geléias, sorvetes, maionese óleo e até cerveja. Apesar disso, somente cerca de $15 \%$ da produção nacional se destina ao consumo humano e, mesmo assim, de maneira indireta na composição de outros produtos (ABIMILHO 2001, BASTOS 1987, FAO 1954).

\subsubsection{Composição do milho}

Pertencente à família das Graminae, a semente do milho é composta pelo envoltório, endosperma e gérmen. Possui teor de proteina variando entre $8-10 \%$, amido $70-80 \%$, lipídeos $4-7 \%$. Entretanto, as diversas partes do grão possuem composição química diferente.

Figura : Componentes do grão de milho

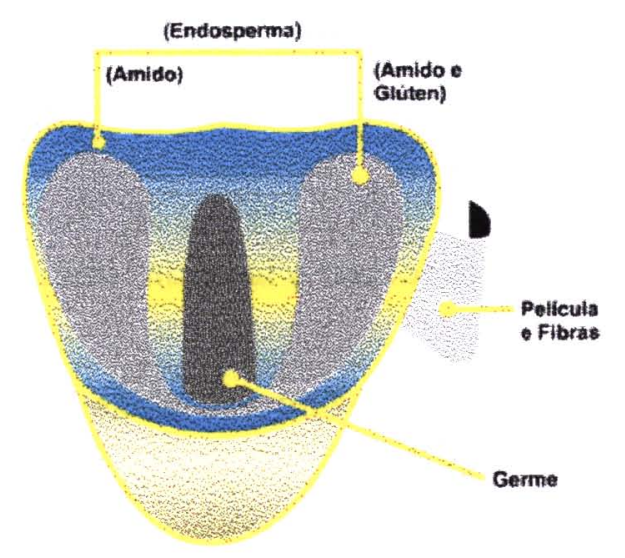

Fonte: Abimilho, 2001 
grão de milho, quando cortado na vertical, revela seus componentes básicos. São eles:

Endosperma - corresponde à maior parte do grão de milho e é composto basicamente de amido (quase $61 \%$ ), além de outros $7 \%$ de glúten que envolve os grânulos de amido e de pequena porcentagem de gordura e demais componentes.

Película - é a parte que recobre o grão. Devidamente processada, ela é empregada como ingrediente em rações animais.

Água - corresponde a aproximadamente $16 \%$ do grão de milho. A água também é utilizada no processo inicial de maceração. O liquor resultante da maceração é rico em vitaminas, especialmente do complexo B. Ele é normalmente usado em rações, além de ser aplicado na fabricação de antibióticos.

Germe - é a parte vegetativa do grão e fonte de óleo do milho. O germe é um componente importante para alimentos, produtos farmacêuticos e aplicações industriais. As frações remanescentes do germe são processadas e podem ser utilizadas como ingredientes em rações animais. (ABIMILHO 2001, POMERANZ 1987, FAO 1954).

\subsubsection{Milho - cenário mundial e nacional}

O milho é cultivado na maioria dos paises, o que o torna o segundo cereal mais importante em termos da produção mundial, sendo suplantado apenas pelo trigo. 
Os Estados Unidos, a China e o Brasil figuram como os principais países produtores deste cereal, e também como os maiores consumidores. A produção de milho, no mundo, concentra-se no hemisfério norte, sendo $40 \%$ nos Estados Unidos, $22 \%$ na China e 5,8 na União Européia. O consumo por sua vez tem a mesma trajetória, $32 \%$ do milho produzido no mundo é utilizado nos E.U.A e $20 \%$ na China.

O Brasil é o terceiro maior produtor mundial, ficando atrás somente da China e dos Estados Unidos, tendo sido um país exportador, e é o primeiro do Mercosul, onde participa com $70 \%$ do total produzido. Neste bloco econômico a Argentina é o segundo produtor correspondendo a $28 \%$ da fração de mercado. Verifica-se que a produção mundial teve um incremento de $1,5 \%$ nos últimos quatro anos, enquanto que, o consumo superando a produção, cresceu em $4,4 \%$.

A safra brasileira de 1999/2000 teve estimativas de uma produção de 33,6 milhões de toneladas/ano, não sendo suficiente para suprir a demanda interna. Atualmente, a produção nacional rende, em média, 2,6 toneladas por hectare, enquanto que a produção mundial alcança a marca de 6,5.

A área cultivada no Brasil pouco variou ao longo das últimas décadas, permanecendo na faixa de 9 a 13,69 milhões de ha. $O$ que realmente modificou foi o rendimento médio por área, que teve um incremento de $88 \%$ (ABIMILHO, 2001). 
Figura 5: Consumo de milho no Brasil por segmento (mil toneladas)

\begin{tabular}{|c|c|c|c|}
\hline SEGMENTO & \multicolumn{3}{|c|}{ CONSUMO } \\
\hline & 1999 & 2000 & $2001^{*}$ \\
\hline Avicultura & 12,529 & 12,976 & 13,479 \\
\hline Suinocultura & 7,677 & 8,329 & 8,587 \\
\hline Pecuária & 2,652 & 2,691 & 2,772 \\
\hline Outros Animais & 1,480 & 1,498 & 1,528 \\
\hline Consumo Industrial & 4,150 & 4,000 & 4,050 \\
\hline Consumo Humano & 1,458 & 1,476 & 1,505 \\
\hline Perdas/Sementes & 859 & 850 & 998 \\
\hline Exportação & 0 & 0 & 2,550 \\
\hline Outros & 4,495 & 3,480 & 3,622 \\
\hline Total & 35,300 & 35,300 & 39,091 \\
\hline
\end{tabular}

*Estimativa: 2001

Fonte: Abimilho

Figura 6: Evolução do consumo de milho no Brasil

\begin{tabular}{|c|c|c|}
\hline Ano & Consumo & Consumo Industrial \\
\hline $1996-1997$ & 35,912 & 4,150 \\
\hline $1997-1998$ & 35,000 & 4,150 \\
\hline $1998-1999$ & 35,000 & 4,150 \\
\hline $1999-2000$ & 35,300 & 4,150 \\
\hline $2000-2001$ & 35,200 & 4,000 \\
\hline $2001-2002^{*}$ & 39,091 & 4,050 \\
\hline
\end{tabular}

* Estimativa

Fonte: Abimilho 


\subsubsection{Aplicações do milho}

Produzido mundialmente, apresenta três finalidades principais: alimento, forragem para pastagens e matéria-prima para diversos produtos industrializados (FAO, 1954). Dentre os produtos industrializados destacam-se a produção de cereais matinais e snacks, dada a alta capacidade de expansão do milho quando submetido ao processo de extrusão. Entretanto, sua proteina é de baixa qualidade, apresentando deficiência em aminoácidos essenciais como a lisina e o triptofano.

Sendo assim, snacks de milho são frequentemente mencionados como produtos de baixa qualidade nutricional. Entretanto, na América Latina, a grande quantidade ingerida desse cereal na forma de snacks, permite extrapolar que o seu consumo pode ser considerado como uma importante fonte de proteínas e energia (PHILLIPS 1989). Assim, o desenvolvimento de snacks de milho de melhor valor nutritivo passa a ser uma proposta de melhorar a qualidade desse tipo de produto que representa hábito de consumo, além de ser potencial importante veículo para nutrientes que são deficientes entre a população (ALMEIDA-DOMINGUEZ et al 1990).

\subsubsection{Pulmão bovino}

A produção de snacks de melhor valor nutritivo pode ser obtido por combinações de cereais com outros componentes alimentares e para tal, existe uma série de matérias-primas que ainda são subutilizadas por não preencherem requisitos sensoriais básicos, como é o caso dos subprodutos de abatedouros. Esses materiais não fazem parte do hábito alimentar da população mas podem ser incorporados à alimentação pelo seu elevado potencial nutritivo e baixo custo (AREAS 1992). 
Dentre os subprodutos de abatedouro, o pulmão bovino apresenta elevado valor nutricional, especialmente no que diz respeito ao teor de ferro, apesar de sua textura indesejável. Desta forma, o processo de extrusão tem sido utilizado com a finalidade de aumentar a aceitabilidade dessa matéria-prima (PINTO et al 1997; CAMPOS E AREAAS 1993; BASTOS e ARÊAS 1990; AREAAS E LAWRIE 1984). Apesar do grande progresso verificado nessa área, os produtos obtidos a partir da extrusão do pulmão bovino não atendem a todos os requisitos organolépticos que possam permitir sua exploração comercial. As condições de extrusão que produziram melhor textura foram aquelas que resultaram em um maior dano ao aproveitamento biológico de proteína. O ferro não teve sua disponibilidade alterada pela extrusão do pulmão, podendo esses produtos serem explorados mais como uma fonte potencial de ferro do que de proteina (PINTO et al 1997; CAMPOS e ARÉAS 1993).

Assim, foram realizadas tentativas de extrusão de misturas de pulmão bovino com outras matérias-primas, com a finalidade de se ter um enriquecimento em ferro de alta biodisponibilidade em produtos que tradicionalmente apresentam baixo valor nutricional. Dentre elas, um trabalho realizado com misturas contendo grão-de-bico e pulmão bovino. Os resultados obtidos demonstraram que o snack contendo $10 \%$ de pulmão bovino teria capacidade de fornecer aproximadamente um terço da necessidade diária de ferro de uma criança se fossem consumidos $30 \mathrm{~g}$ do snack por dia (CARDOSO-SANTIAGO et al 2001; CARDOSO-SANTIAGO e AREAAS 2001; RDA 1989). Entretanto, sua utilização toma-se limitada, uma vez que a produção de grão-de-bico no Brasil ainda não é suficiente para atingir a demanda necessária para a produção desse snack em larga escala, além do elevado custo quando comparado às matérias-primas já utilizadas para esse fim. Assim, a sua combinação com milho toma o snack obtido um produto viável tecnologicamente e 
comercialmente.

A produção de proteína tem sido largamente estudada e esta fração alimentar necessita ser incorporada em maiores quantidades na alimentação humana principalmente no que diz respeito à proteína animal. Sabe-se que para a sua produção faz-se necessário um elevado gasto energético, o que acarreta a elevação do custo destes componentes da dieta (KINSELLA 1978). Desta forma, verifica-se um aumento na produção e consumo de proteinas de origem vegetal, sem contudo relegar as proteinas de origem animal a um segundo plano, uma vez que estas tem importância nutritiva elevada e existe uma impossibilidade de tornar toda área terrestre cultivável (ARÊAS 1992; MITTAL e LAWRIE 1986; SWINGLER e LAWRIE 1978; SWINGLER et al 1978).

$\mathrm{Na}$ atualidade, o desenvolvimento de técnicas para a recuperação e utilização dos produtos tipo sobra e subutilizados tem gerado formas de transformação e incorporação de fontes pouco usuais em produtos formulados (CARDOSOSANTIAGO e ARÊAS 2001; CONTI e ARÊAS 2001; ARÊAS 1992; GAULT e LAWRIE 1980).

No processamento e produção da came, a indústria produz uma série de subprodutos com elevado valor nutritivo e que deixam de ser consumidos por não preencherem os requisitos básicos de aceitabilidade para esse fim (CAMPOS e AREAS 1993). Assim, grande parte da proteina animal é inaproveitada ou subutilizada para alimentação humana, sendo desviada para alimentação animal ou outros fins não alimentares. Os subprodutos mais importantes incluem sangue, pulmões, baço, esôfago, cérebro, rúmen, intestinos, testículos, úbere e patas, dado seu elevado valor nutritivo e o peso que representam do animal. 
Os fatores limitantes para o consumo destes subprodutos são, principalmente, a rejeição estética incluindo cor, sabor e aroma associados à baixa qualidade textural quando comparado aos demais tecidos animais ou proteinas vegetais texturizadas. Recentemente, tem sido demonstrada a possibilidade de promover um aumento da sua aceitabilidade através de técnicas de transformação e modificação das proteinas (AREAAS 1992; CAMPOS e AREAAS 1993). Dentre elas, a extrusão tem-se mostrado apropriada desde que a matéria-prima seja submetida a tratamentos prévios como secagem e desengorduramento (AREASS e LAWRIE 1984; ARÉAS 1986 a, b; BASTOS e ARÉAS 1990; BASTOS et al 1991; CARDOSO-SANTIAGO e ARÊAS 2001; CONTI e ARÊAS 2001). Não obstante, o uso desta técnica em subprodutos de origem animal resultou até o presente em produtos de baixa qualidade textural (BASTOS e AREAS 1990).

Diversos estudos (CARDOSO-SANTIAGO e AREAS 2001; AREAAS e LAWRIE 1984; BASTOS e ARÊAS 1990; CAMPOS e ARÊAS 1993; MITTAL E LAWRIE 1986; SWINGLER et al 1978) têm sido feitos com pulmão bovino devido ao considerável teor de proteína de boa qualidade quando comparado aos demais residuos, bem como sua digestibilidade relativamente alta, apresentando a vantagem de não sofrer danos na qualidade nutricional da proteina quando texturizado.

O pulmão bovino, igualmente aos demais tecidos animais, apresenta teores de carboidratos despreziveis (AREAAS e LAWRIE 1984; BASTOS et al 1991). Quanto aos teores de lipides, mostram-se bastante elevados, acarretando na necessidade de desengorduramento para obtenção de valores residuais que variam entre 0,5 a $7 \%$, sendo este lípide residual composto basicamente de fosfolipides (ARÊAS 1985; ALCOCER e ARÊAS 1990). Assim, durante o processo de extrusão, a reação de Maillard bem como a oxidação lipídica ocorrem em proporções 
mínimas, permitindo desta forma, uma manutenção da qualidade do produto final, tanto do ponto de vista nutricional quanto sensorial (HARPER 1981; ASP e BJORK 1984).

Outro nutriente importante do pulmão bovino é o ferro que está presente em quantidades significativas, sendo aproximadamente $50 \%$ encontrado na forma heminica. Após o processo de extrusão, a sua biodisponibilidade não é alterada, possibilitando o uso deste tecido como fonte de ferro (CAMPOS e AREAS 1993; PINTO et al 1997).

Desta forma, o uso em grande escala de proteínas de origem animal para extrusão tem sido tentado para se obter produtos análogos à carne, a partir de resíduos de abatedouro (SWINGLER et al 1978; CAMPOS e ARÉAS 1993). Entretanto, a formação de produtos extrusados a partir de subprodutos como o pulmão, tem apresentado melhor textura quando adicionado de leguminosas, mais comumente a soja (CARDOSO-SANTIAGO e AREAS 2001; AREAS e LAWRIE 1984; BASTOS e ARÉAS 1990; MITTAL e LAWRIE 1986), podendo ser adicionado ainda de cereais, como o milho, tornando-o mais próximo aos produtos comerciais (MOREIRA-ARAÚJO et al 2002). Inicialmente, o custo do produto é incompatível com a produção da indústria alimenticia, mesmo atingindo algumas das caracteristicas recomendadas para fortificação de alimentos, sendo necessário a utilização de técnicas de otimização do processo além da busca de alternativas para a diminuição do custo do processo, como por exemplo, eliminação de etapas de preparo do pulmão previamente à extrusão (LINS e SILVA 2000). 
Um estudo recente de viabilidade econômica de snacks de milho fortificados com sulfato ferroso, Ferrocheほ e pulmão bovino demonstrou um aumento de custo apenas nos dois últimos, sendo esse acréscimo de 1,3 e 9,3\%, respectivamente. Apesar desse acréscimo no custo, fatores como a melhora da qualidade nutricional, bem como a biodisponibilidade de ferro devem ser consideradas na decisão pela produção em escla industrial (MARCHI 2002).

\subsection{Extrusão termoplástica}

A extrusão para indústria de alimentos teve um grande desenvolvimento a partir de 1946 quando a Adams Company iniciou a produção de snacks de milho, sendo, posteriormente aplicada para a produção de cereais matinais, bem como para um grande número de novos produtos extrusados (GUY 1985). Processo essencialmente HTST (high temperature-short time), sua utilização na indústria de alimentos busca agregar atributos aos ingredientes que sejam caracteristicos desses produtos prontos para consumo. Além disso, a extrusão apresenta uma série de vantagens frente a outras formas de processamento de alimentos, dentre elas a continuidade do processo e o baixo custo (MAGA 1991; COLONNA et al 1989; SMITH 1976).

Nesse processo se promove uma compressão do material parcialmente umedecido a altas temperaturas e pressões, tipicamente $120-170^{\circ} \mathrm{C}$ e 4-5 MPa, respectivamente, por um período curto, 4-5 segundos na temperatura máxima (AREAS 1992). Sendo assim, uma extrusora pode ser definida como um reator, capaz de processar biopolímeros e misturas de ingredientes em temperaturas elevadas, sob alta pressão e força de cisalhamento a umidades relativamente baixas. Essas características do processo promovem um aumento na pressão que resulta numa fricção entre a rosca e as paredes do canhão, gerando calor e 
consequente cozimento da matéria prima. Nesta fase, o máximo de temperatura e pressão na matéria-prima são atingidos e, ao ser forçada contra o orifício de saída, a água contida no material imediatamente evapora obtendo-se assim um produto expandido. Para assegurar a crocância e estabilidade dos produtos obtidos eles sofrem uma secagem após o processamento, mesmo contendo baixa umidade à saida do extrusor. A princípio, qualquer matéria-prima pode ser extrusada, todavia na prática, faz-se necessário o uso de materiais que tenham a capacidade de se solidificar ao sair da extrusora, mantendo a estrutura desejada. Ingredientes variados, como cereais, leguminosas e subprodutos animais, resultam em produtos com características fisico-químicas e texturais diferentes. O processo de extrusão apresenta ainda a vantagem de provocar uma perda mínima de nutrientes e a desvantagem de ocasionar alterações em sabor e cor de alguns produtos submetidos ao processo. (AREAAS 1992; CAMIRE et al 1990; POMERANZ 1987; DIXON 1983; MATSON 1982; KINSELLA 1978; ROSSEN e MILLER 1973).

Dentre os produtos obtidos por essa tecnologia, o snack tem alta aceitabilidade e um mercado que apresenta crescimento anual que varia de 10 $15 \%$ ao ano. Na sua produção, os ingredientes mais comuns são as farinhas de milho e batata, devido sua capacidade de expansão, bem como a neutralidade de sabor e o baixo custo (MATSON 1982). 


\subsection{Análise sensorial}

A avaliação sensorial de alimentos é uma função primária do ser humano, que consciente ou inconscientemente aceita ou rejeita os alimentos de acordo com a sensação percebida ao ingerir o mesmo (STONE e SIDEL, 1991). Essa capacidade interfere diretamente na produção de alimentos que está sempre buscando uma qualidade sensorial que atenda as expectativas de quem irá ingerí-lo (PLATT 1931 citado por SILVA 2000).

Sendo assim, a evolução tecnológica da indústria de alimentos vem determinando os métodos mais apropriados para avaliação da qualidade sensorial. Segundo alguns autores, podem ser descritas quatro fases na metodologia da avaliação da qualidade sensorial (COSTELL e DURAN 1981 citado por SILVA 2000). A primeira ocorreu antes de 1940 e se baseou em avaliações artesanais, geralmente realizadas pelo proprietário ou encarregado da indústria. A introdução de pessoal técnico, bem como de conceitos de controle de processo e produto final, se deu entre 1940 e 50, quando foram introduzidos a utilização de métodos químicos e instrumentais. Até então, a avaliação sensorial não tinha sido utilizada como ferramenta para indústria alimenticia. A partir da Segunda Guerra, a necessidade de melhorar a ração dos soldados americanos alavancou o início de financiamentos para o desenvolvimento de métodos para avaliar a qualidade sensorial de alimentos, sendo essa fase determinante na utilização do homem como instrumento de avaliação. Finalmente, após os anos 70 , a qualidade sensorial passa a ser o resultado da interação entre o homem e o alimento que utiliza suas caracteristicas fisiológicas, psicológicas e sociológicas para reconhecer os estímulos procedentes dos alimentos. 
Desde então, a participação humana tem sido fundamental no desenvolvimento do que se conhece hoje como Análise sensorial, que segundo o IFT (Institute of Science and Technology) é uma disciplina usada para provocar, medir, analisar e interpretar as reações produzidas pelas caracteristicas dos alimentos e materiais, como elas são percebidas pelos órgãos da visão, olfato, gosto, tato e audição (STONE e SIDEL 1991). Resumidamente, o homem avalia a qualidade sensorial pelo seguinte processo:

Caracteristicas fisicas e quimicas

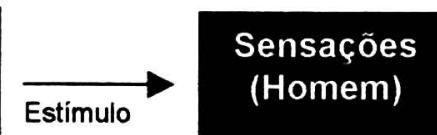

Os métodos de avaliação sensorial podem ser divididos em três grande grupos (SILVA, 2000):

- Discriminativos ou de diferença - determinam se as amostras que sofrem diferentes tratamentos diferem sensorialmente entre si.

- Descritivos ou analíticos - envolvem a discriminação e descrição dos atributos sensoriais de um produto. Podem ser descritivos, uma vez que descrevem as amostras em termos sensoriais, e quantitativos por avaliarem numericamente a intensidade de cada atributo.

- Afetivos - avaliam a preferência ou aceitação de um produto junto ao mercado consumidor. 
Sendo assim, a análise sensorial torna-se uma ferramenta de grande valia no desenvolvimento de novos produtos, auxiliando na detecção de diferenças e preferências por determinados produtos, na seleção de um processo adequado, na determinação do grau ou nivel de qualidade de um produto $e$, finalmente na preferência do consumidor (MORAES 1985). 


\section{OBJETIVOS:}

\subsection{Objetivo geral}

Desenvolver um produto de alta aceitabilidade para crianças e adolescentes que seja uma boa fonte de ferro.

\subsection{Objetivos específicos}

Otimizar o processo de extrusão para a produção de "snacks" de milho e pulmão bovino, tendo como resposta os parâmetros texturais correlacionados com aceitabilidade do produto.

Produzir um alimento pronto para o consumo de alta aceitabilidade entre os jovens, que forneça de $30-40 \%$ das necessidades diárias de ferro. 


\section{METODOLOGIA}

\subsection{Materiais:}

\subsubsection{Matéria-prima:}

\subsubsection{Milho}

Milho (Zea maiz L.): foi adquirido na forma de sêmola de milho (Caramuru Alimentos de Milho Ltda, Itumbiara-GO), na granulometria de 0,84mm (mínimo $90 \%$ ). O material permaneceu armazenado em sacos de polipropileno em local seco e arejado até preparo para extrusão. A granulometria do produto foi estabelecida antes do início do processo de otimização através de testes com fubá, gritz e quirela.

\subsubsection{Pulmão bovino}

O pulmão bovino foi fornecido pelo Frigorífico Goiás Cames (Goiânia-GO), sob inspeção Sanitária Federal. Este material foi seco por desidratação à vácuo e moido. O material seco e moido foi armazenado em sacos de polipropileno, a temperatura ambiente, em local seco e arejado, até preparo para extrusão.

Para extrusão, as farinhas foram umedecidas previamente à mistura a fim de manter a homogeneidade de expansão dos snacks produzidos. A adição de água foi feita em um silo com uma rosca sem fim, na posição vertical, no seu interior, para homogenização das misturas e da água adicionada .

Foram utilizadas misturas de milho e pulmão bovino na proporção de $90-10 \%$, respectivamente, sendo essa concentração de farinha de pulmão capaz de fornecer aproximadamente $30 \%$ da RDA (1989) de ferro na dieta no consumo de $30 \mathrm{~g}$ de produto (CARDOSO-SANTIAGO et al 2001; PINTO et al 1997). 


\subsubsection{Snacks}

Os snacks obtidos na produção em larga escala foram avaliados sensorialmente pelas crianças que frequentam o Centro da Juventude Paulo de Tarso (CJ).

Os snacks de milho e de milho com pulmão bovino (90:10) foram aromatizados com sabor bacon e embalados em sacos próprios para snacks em pacotes de 30 e $35 \mathrm{~g}$, respectivamente.

\subsection{Métodos}

\subsubsection{Análises químicas:}

A determinação química das diferentes amostras de milho, pulmão bovino $e$ sua mistura foi realizada em triplicata. As análises de composição centesimal seguiram os métodos descritos pelo INSTITUTO ADOLFO LUTZ (1985) e ASSOCIATION OF OFFICIAL ANALYTICAL CHEMISTS-AOAC (1990).

A determinação de ferro total foi realizada por espectrometria de emissão atômica com plasma indutivo, na Central Analítica do Departamento de Química Fundamental no Instituto de Quimica da USP. 


\subsubsection{Extrusão do material:}

Para otimização do processo de extrusão do material foi utilizada extrusora de laboratório de rosca única (Miotto Ltda-São Bernardo do Campo-São Paulo), no Laboratório de Propriedades Funcionais de Alimentos, da Faculdade de Saúde Pública/USP. O equipamento apresenta diâmetro interno de $20 \mathrm{~mm}$ com uma relação comprimento/diâmetro 20:1. O cilindro é dividido em três zonas, sendo o sistema aquecido composto por três resistências elétricas, independentes para cada zona. O controle da temperatura é feito por termopares, sendo a sua manutenção através de refrigeração com água e ar, cujo controle é feito através de válvulas solenóides. A alimentação do extrusor é feita por um funil contendo rosca condutora. Acoplado à extrusora há um painel de controle das variáveis temperatura, rotação da rosca e velocidade de alimentação. As condiçōes de extrusão adotadas variaram de acordo com a variáveis independentes estabelecidas para o experimento.

Os dados da otimização foram utilizados numa extrusora com capacidade de produção industrial (modelo Inbra 120, INBRAMAQ - Indústria de Máquinas Ltda, Ribeirão Preto-SP) para produção dos snacks em larga escala. O equipamento apresenta rosca única, cônica, paralela, sendo o sistema aquecido composto por resistências elétricas, independentes para cada zona. O controle da temperatura é feito por termopares, sendo a sua manutenção através de refrigeração com água,

cujo controle é feito através de válvulas solenóides. A alimentação do extrusor é feita por um silo com a dosagem por gravidade. Acoplado à extrusora há um painel de controle das variáveis temperatura, rotação da rosca e velocidade de alimentação, velocidade de corte. 
As condições de extrusão adotadas para produção em larga escala de snacks de milho e milho/pulmão bovino, foram adaptadas a partir da otimização realizada com milho e foram fixadas em:

- Umidade: $16-17 \%$

- Camisa: cônica, helicoidal

- Rosca: cônica, paralela, passo normal

- Taxa de compressão da rosca:1:1

- Velocidade da rosca: $400 \mathrm{rpm}$

- Input de energia: 36 - $42 \mathrm{~A}$

- Matriz: 6 furos de $3,2 \mathrm{~mm}$

- Sub-matriz: 114 furos de $3,2 \mathrm{~mm}$

- Temperatura: $70^{\circ} \mathrm{C}$

A extrusão da mistura e do milho foi realizada nas mesmas condições e os snacks obtidos foram aromatizados com sabor bacon nas seguintes condições:

- Aroma: $4 \%$

- Sal: $0,9 \%$ (produto final com $2,5 \%$ de sal)

- Óleo de canola: $15 \%$

\subsubsection{Metodologia de Superfície de Resposta (MSR)}

A otimização do processo foi realizada por MSR considerando como variáveis independentes do processo: umidade da amostra, temperatura da região central da extrusora, velocidade de rotação da rosca e velocidade de alimentação e, como variáveis dependentes: razão de expansão. 
Para descrição do processo empregou-se uma equação polinomial de segunda ordem, obtida através de análise de regressão múltipla do efeito das variáveis independentes nas variáveis resposta:

$$
\begin{aligned}
& y=B_{0}+B_{1} x_{1}+B_{2} x_{2}+\ldots+B_{n} x_{n}+B_{11} x_{1}{ }^{2}+B_{2} x_{2}{ }^{2}+\ldots+B_{n n} x_{n}{ }^{2}+B_{1 n} x_{1} x_{2} \ldots x_{n}+E \\
& \text { onde: }
\end{aligned}
$$

y: resposta determinada no produto final

$B_{0}, B_{1}, \ldots B_{n}:$ constantes

$x_{1}, x_{2}, \ldots x_{n}$ : variáveis independentes consideradas

E: erro experimental com distribuição normal, média zero e variância $\delta^{2}$

Durante o experimento foi determinado a região onde a variável resposta melhor responde às variáveis independentes.

\subsubsection{Otimização da condições de extrusão}

Baseando-se nos resultados de ensaios prévios e experiência anterior para vários tipos de materiais (CAMPOS e AREAAS 1993; BATISTUTI et al 1991; BASTOS et al 1991; BASTOS e AREAS 1990; BARROS et al 1987) as variáveis independentes escolhidas foram: umidade do material, temperatura da região central da extrusora e velocidade de rotação da rosca.

Assim, baseado em dados anteriores do laboratório, foi inicialmente testado como ponto central das variáveis independentes: $13 \%$ de umidade $\left(X_{1}\right) ; 150^{\circ} \mathrm{C}$ de temperatura $\left(X_{2}\right) ; 166 \mathrm{rpm}$ para rotação da rosca $\left(X_{3}\right)$. Os intervalos entre os niveis foram de $2 \%, 10^{\circ} \mathrm{C}$ e $20 \mathrm{rpm}$, respectivamente. 
A fim de obter um delineamento com máxima resposta foram realizadas variações da intensidade das variáveis independentes ao redor do ponto central, com a combinação de experimentos mostrados nas tabelas que se seguem (Tabelas 2, 5, 8, 11 e 12).

As demais variáveis foram fixadas a partir de experimentos prévios em:

Velocidade do dosador: $40 \mathrm{rpm}$, que resulta numa taxa de alimentação ao redor de $70 \mathrm{~g} \cdot \mathrm{min}^{-1}$ para maioria dos materiais.

Orificio de saida: $3 \mathrm{~mm}$

Taxa de compressão da rosca: $3,55: 1$

A partir dos resultados obtidos, algorítimos de trajetória de maior incremento foram empregados na determinação de novos pontos centrais e novos intervalos de variação para as variáveis independentes (BOX e DRAPER 1987).

A análise dos dados foi realizada com pacote de programas estatisticos STATGRAPHICS (Statistical Graphics Corporation. USA, STSC Inc., 1987) e a apresentação gráfica através de superfícies de resposta obtidas no programa Origin (Microcal Inc., USA, 1997). 


\subsubsection{Avaliação mecânica dos extrusados}

\subsubsection{Razão de expansão}

Foi obtida pelo quociente entre o diâmetro dos extrusados e o diâmetro do orifício de saida do extrusor. Para a medida do diâmetro do extrusados foi utilizado um paquímetro Mitutoyo. Em cada tipo de snack foram feitas 30 medidas aleatórias.

\subsubsection{Força para cisalhamento completo}

A medida de força para cisalhamento completo foi realizada nos snacks aromatizados, prontos para o consumo, e com forma de bola de aproximadamente $1,5 \mathrm{~cm}$ utilizando equipamento TAXT2i, utilizando software "Texture Expert" (Stable Systems, 1999) equipado com cela Universal. Para cada amostra foram feitas 30 medidas.

\subsubsection{Análise sensorial:}

Foi realizado um teste de aceitabilidade utilizando escala hedônica facial de 5 pontos (Anexo 1). A escala facial é modificada da descritiva, sendo as expressões "gostei muitíssimo" a "desgostei muitíssimo" substituidas por caretas que expressam a aceitabilidade. Esta escala é usada principalmente para crianças que não sabem ler e a elas é solicitado que registrem a careta que melhor descreve o quanto gostou ou desgostou da amostra. Para avaliação dos resultados, cada careta recebe um valor e os dados são avaliados estatisticamente (MORAES, 1985). 
O painel selecionado para avaliação constou de crianças e adolescentes frequentadores do CJ Paulo de Tarso, variando entre 6 e 15 anos de ambos sexos. Os provadores receberam, em dias diferentes, snacks sabor bacon de milho/pulmão bovino e de milho respectivamente. $O$ grupo foi dividido pela idade $e$ colocado em mesas de seis lugares com quatro individuos por mesa para evitar troca de informações, receberam também esclarecimentos sobre o preenchimento da ficha de avaliação. As amostras foram oferecidas em copos plásticos de $50 \mathrm{ml}$ acompanhados de um copo com água para ingerir após a avaliação (MORAES, 1985).

Para verificar diferenças entre as médias foi realizado analise de variância e teste de Tukey $(p<0,05)$. 


\section{RESULTADOS E DISCUSSÃO}

\subsection{Composição centesimal}

A composição centesimal do gritz de milho, do pulmão bovino e dos snacks obtidos na produção em larga escala encontram-se na Tabela 1.

Tabela 1: Composição centesimal $(\mathrm{g} / 100 \mathrm{~g})$ e de ferro total $(\mathrm{mg} / 100 \mathrm{~g})$ do milho e pulmão bovino e dos extrusados de milho e milho/pulmão bovino em base seca.

\begin{tabular}{cccccc}
\hline Amostra & Proteína & Lipídeos & Cinzas & $\begin{array}{c}\text { Carboidratos } \\
\text { totais }^{\mathrm{b}}\end{array}$ & Ferro total $^{\text {Gritz de milho }}$ \\
\hline Pulmão bovino & 7,43 & 0,71 & 0,46 & 91,4 & 1,80 \\
Pulmão bovino integral & 94,1 & $1,08^{\mathrm{c}}$ & 5,79 & - & 58,2 \\
Mistura gritz/pulmão bovino & 69,1 & 24,8 & 6,10 & - & 58,2 \\
Snack de milho & 13,6 & 3,11 & 1,00 & 82,3 & 9,45 \\
Snack milho/pulmão bovino $^{\mathrm{a}}$ & 6,33 & 14,8 & 2,31 & 76,6 & 1,22 \\
\hline
\end{tabular}

aromatizado com $15 \%$ de óleo de canola

obtido por diferença

' determinado após desengorduramento à frio por extração em Soxhlets com clorofórmio:metanol 2:1.

Os resultados obtidos para composição centesimal do gritz de milho e seus extrusados com e sem pulmão bovino estão coerentes com os dados da literatura (ASCHERI e CARVALHO 1996; COULTER e LORENZ 1991; GONZÁLEZ et al 1987). O milho é considerado um alimento fonte de energia devido seu elevado conteúdo de carboidratos que, do ponto de vista funcional, interfere diretamente na textura dos extrusados permitindo a obtenção de snacks com maior razão de expansão (POMERANZ 1987). 
Diversos estudos (MOREIRA-ARAÚJO et al 2002; CARDOSO-SANTIAGO e ARÉAS 2001; CARDOSO-SANTIAGO et al 2001; CASSAR 2000) tem demonstrado que o pulmão bovino é uma excelente fonte de ferro e proteinas de elevado valor biológico. Entretanto, sua inadequação textural e seu sabor característico, fazem com que seja necessária sua inclusão como ingrediente em produtos de alta aceitabilidade, que possam ter sua textura alterada e seu sabor minimizado pela adição de aromas e realçadores de sabor.

Após a extrusão, verificou-se uma tendência à diminuiçào do teor de proteina, provavelmente em função das condições do processamento. Estudos demonstram que esta perda da qualidade nutritiva pode ser consequência da fragmentação molecular, ocorrida pelo baixo teor de umidade e alto cisalhamento e temperatura, que levam à associaçōes irreversiveis (CAMPOS e AREAS 1993; CHEFTEL 1986). Apesar dessa tendência, o processo de extrusão não alterou significativamente a composição das farinhas.

Tendo como meta a produção de um snack com teores de ferro que representem de 30 a $40 \%$ das necessidades diárias de crianças, no consumo de 30 $\mathrm{g}$ três vezes por semana, procedemos à otimização inicial do snacks de milho, com adição posterior da farinha de pulmão (suplemento de ferro).

O produto de milho e pulmão bovino obtido foi um snack com elevado conteúdo de ferro, mas com capacidade de suprir de 25 a $15 \%$ da necessidade diária desse mineral para crianças da idade pré-escolar até a adolescência. Essa suplementação mostrou-se suficiente para intervenções nutricionais com produto semelhante (CARDOSO-SANTIAGO et al 2001). 


\subsection{Otimização da extrusão do snack de millho para razão de expansão}

O delineamento $\left(E_{1}\right)$ inicialmente adotado foi:

Tabela 2: Delineamento experimental $\left(E_{1}\right)$ e razão de expansão obtidos em função da umidade da amostra, temperatura de extrusão e rotação da rosca.

\begin{tabular}{|c|c|c|c|c|c|c|c|}
\hline \multirow[t]{2}{*}{ Ensaios } & \multicolumn{3}{|c|}{ Variáveis Codificadas } & \multicolumn{3}{|c|}{ Variáveis Originais } & \multirow{2}{*}{$\begin{array}{c}\text { Razão de } \\
\text { expansão } \\
X( \pm D P)\end{array}$} \\
\hline & $\begin{array}{c}x_{1} \\
(U-13) / 2\end{array}$ & $\begin{array}{c}x_{2} \\
(T-150) / 10\end{array}$ & $\begin{array}{c}x_{3} \\
(R-166) / 20\end{array}$ & $\begin{array}{l}X_{1} \\
(U)\end{array}$ & $\begin{array}{l}X_{2} \\
(T)\end{array}$ & $\begin{array}{l}X_{3} \\
(R)\end{array}$ & \\
\hline 1 & -1 & -1 & -1 & 11 & 140 & 146 & $3,58 \pm 0,34$ \\
\hline 2 & -1 & 1 & 1 & 11 & 160 & 186 & $3,61 \pm 0,33$ \\
\hline 3 & 1 & -1 & 1 & 15 & 140 & 186 & $3,59 \pm 0,38$ \\
\hline 4 & 1 & -1 & -1 & 15 & 140 & 146 & $3,44 \pm 0,28$ \\
\hline 5 & 0 & 0 & 0 & 13 & 150 & 166 & $3,95 \pm 0,45$ \\
\hline 6 & 0 & 0 & 0 & 13 & 150 & 166 & $3,74 \pm 0,35$ \\
\hline 7 & -1 & -1 & 1 & 11 & 140 & 186 & $3,61 \pm 0,35$ \\
\hline 8 & -1 & 1 & -1 & 11 & 160 & 146 & $3,56 \pm 0,35$ \\
\hline 9 & 1 & -1 & -1 & 15 & 140 & 146 & $3,79 \pm 0,48$ \\
\hline 10 & 1 & 1 & 1 & 15 & 160 & 186 & $3,42 \pm 0,48$ \\
\hline 11 & 0 & 0 & 0 & 13 & 150 & 166 & $3,58 \pm 0,37$ \\
\hline 12 & 0 & 0 & 0 & 13 & 150 & 166 & $3,65 \pm 0,36$ \\
\hline 13 & 1,68179 & 0 & 0 & 16,36 & 150 & 166 & $3,39 \pm 0,62$ \\
\hline 14 & $-1,68179$ & 0 & 0 & 9,64 & 150 & 166 & $3,50 \pm 0,26$ \\
\hline 15 & 0 & 1,68179 & 0 & 13 & 166,82 & 166 & $3,31 \pm 0,31$ \\
\hline 16 & 0 & $-1,68179$ & 0 & 13 & 133,18 & 166 & $3,67 \pm 0,38$ \\
\hline 17 & 0 & 0 & 1,68179 & 13 & 150 & 200 & $3,55 \pm 0,41$ \\
\hline 18 & 0 & 0 & $-1,68179$ & 13 & 150 & 132 & $3,67 \pm 0,47$ \\
\hline 19 & 0 & 0 & 0 & 13 & 150 & 166 & $3,59 \pm 0,34$ \\
\hline 20 & 0 & 0 & 0 & 13 & 150 & 166 & $3,39 \pm 0,46$ \\
\hline
\end{tabular}


Tabela 3: Análise de regressão múltipla para o modelo de Segunda ordem da variável razão de expansão $(Y)\left(E_{1}\right)$

\begin{tabular}{lccc}
\hline \multicolumn{1}{c}{ Fonte de variação } & Coeficiente & t-estimativa & Nivel de significância \\
\hline Constante & 3,648906 & 55,6623 & 0,0000 \\
$x_{1}$ (umidade) & $-0,042422$ & $-0,9012$ & 0,3886 \\
$x_{2}$ (temperatura) & $-0,076127$ & $-1,6088$ & 0,1387 \\
$x_{3}$ (rotação da rosca) & $-0,004939$ & $-0,1049$ & 0,9185 \\
$x_{1}{ }^{2}$ & $-0,065326$ & $-1,5253$ & 0,1582 \\
$x_{2}{ }^{2}$ & $-0,049416$ & $-1,1538$ & 0,2754 \\
$x_{3}{ }^{2}$ & $-0,006989$ & $-1,1632$ & 0,8736 \\
$x_{1} x_{2}$ & $-0,049276$ & $-0,7566$ & 0,4668 \\
$x_{1} x_{3}$ & $-0,003205$ & $-0,0496$ & 0,9614 \\
$x_{2} x_{3}$ & 0,011776 & 0,1808 & 0,8601 \\
\hline
\end{tabular}

Tabela 4: Análise de variância para razão de expansão $\left(E_{1}\right)$

\begin{tabular}{lllllll}
\hline & $\begin{array}{c}\text { Soma de } \\
\text { quadrados }\end{array}$ & $\begin{array}{c}\text { Grau de } \\
\text { liberdade }\end{array}$ & $\begin{array}{c}\text { Média } \\
\text { quadrática }\end{array}$ & $\begin{array}{c}F- \\
\text { calculado }\end{array}$ & $\begin{array}{c}\text { P-nivel de } \\
\text { significância }\end{array}$ & $\begin{array}{c}\text { F-tabelado } \\
(5 \%)\end{array}$ \\
\hline Modelo & 0,169406 & 9 & 0,0188229 & 0,728753 & 0,6774 & 3,02 \\
Erro & 0,258289 & 10 & 0,0258289 & & & \\
\hline
\end{tabular}

Total (corr.) $\quad 0,427695 \quad 19$

$$
R^{2}=0,3961
$$

Nos processos de extrusão, um modelo polinomial que responder aproximadamente $90 \%$ das variações é considerado bom. Ou seja, quanto maior for a fração descrita pela regressão, melhor será o ajuste do modelo. Com a finalidade de quantificar esta fração, calcula-se o valor de $R^{2}$, que é a razão entre a soma dos quadrados do residuo e a soma dos quadrados totais. $O$ maior valor possivel para $R^{2}$ é um, e ele só ocorrerá se não houver resíduo algum e portanto toda a variação em tomo da média for explicada pela regressão (AGUILERA e KOSIKOWSKI 1976; BARROS NETO et al 1995). 
No delineamento usado como ponto inicial e baseado em experiências prévias para o tipo de material, os resultados da análise de variância para razão de expansão (Tabela 4) indicaram que o modelo respondeu por apenas $40 \%$. Ainda assim, para efeito de estudo, foram tomados como significativos a temperatura $\left(x_{2}\right)$, os efeitos quadráticos da umidade $\left(\mathrm{x}_{1}{ }^{2}\right)$ e da temperatura $\left(\mathrm{x}_{2}{ }^{2}\right)$ que foram os coeficientes mais próximos da significância. As demais fontes de variação não apresentaram nenhuma significância, sendo obtida uma primeira equação preditiva, para análise da tendência de variação observada:

$$
Y=3,65-0,08 x_{2}-0,06 x_{1}^{2}-0,05 x_{2}^{2}
$$

Nota-se, nesse modelo, que a rotação da rosca não afetou os resultados, podendo ser fixada nos próximos experimentos.

A partir da superfície de resposta obtida com essa equação (Figura 7), verificou-se uma tendência à maior expansão em umidades entre 12 a $15 \%(-0,5$ a 1 codificada). Sendo assim, a partir desses resultados um novo delineamento foi proposto buscando ampliar a faixa de umidade estudada, para observar se os extremos desta variável apresentariam uma expansão crescente ou decrescente. A temperatura foi mantida, e a rotação da rosca, por sua baixa significância (valores sempre próximos a 1), foi excluida. 


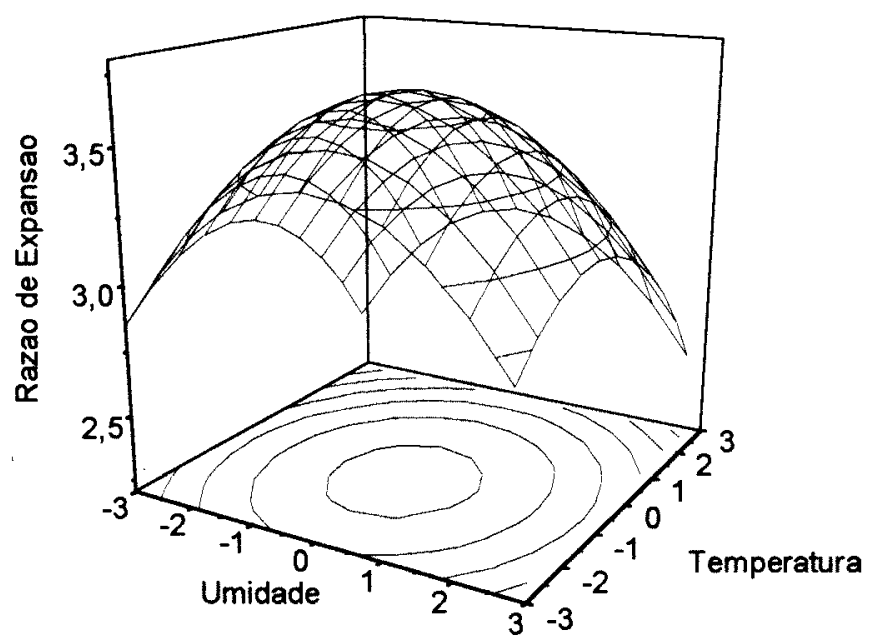

Figura 7: Superfície de resposta do extrusado de milho para razão de expansão em função da umidade e temperatura $\left(E_{1}\right)$ 
O segundo delineamento adotado $\left(E_{2}\right)$ foi o composto central rotacional (BARROS-NETO et al, 1995).

Tabela 5: Delineamento experimental $\left(E_{2}\right)$ e razão de expansão obtidos em função da umidade da amostra e temperatura de extrusão.

\begin{tabular}{|c|c|c|c|c|c|}
\hline \multirow[t]{2}{*}{ Ensaios } & \multicolumn{2}{|c|}{$\begin{array}{l}\text { Variáveis } \\
\text { Codificadas }\end{array}$} & \multicolumn{2}{|c|}{$\begin{array}{l}\text { Variáveis } \\
\text { Originais }\end{array}$} & \multirow{2}{*}{$\begin{array}{l}\text { Razão de } \\
\text { expansão } \\
X( \pm D P)\end{array}$} \\
\hline & $\begin{array}{c}x_{1} \\
(U-13) / 3\end{array}$ & $\begin{array}{c}x_{2} \\
(T-150) / 10\end{array}$ & $\begin{array}{l}X_{1} \\
\text { (U) }\end{array}$ & $\begin{array}{l}X_{2} \\
(T)\end{array}$ & \\
\hline 1 & -1 & -1 & 10 & 140 & $3,54 \pm 0,42$ \\
\hline 2 & -1 & 1 & 10 & 160 & $3,78 \pm 0,57$ \\
\hline 3 & 1 & -1 & 16 & 140 & $3,84 \pm 0,84$ \\
\hline 4 & 1 & 1 & 16 & 160 & $3,68 \pm 0,70$ \\
\hline 5 & 0 & 0 & 13 & 150 & $3,94 \pm 0,34$ \\
\hline 6 & 0 & 0 & 13 & 150 & $3,69 \pm 0,40$ \\
\hline 7 & 0 & 0 & 13 & 150 & $3,84 \pm 0,43$ \\
\hline 8 & 1,41421 & 0 & 17,24 & 150 & $3,59 \pm 0,66$ \\
\hline 9 & $-1,41421$ & 0 & 8,76 & 150 & $3,63 \pm 0,44$ \\
\hline 10 & 0 & 1,41421 & 13 & 164,14 & $3,73 \pm 0,33$ \\
\hline 11 & 0 & $-1,41421$ & 13 & 135,8 & $4,01 \pm 0,31$ \\
\hline 12 & 0 & 0 & 13 & 150 & $3,92 \pm 0,47$ \\
\hline 13 & 0 & 0 & 13 & 150 & $3,74 \pm 0,56$ \\
\hline 14 & 0 & 0 & 13 & 150 & $3,83 \pm 0,11$ \\
\hline
\end{tabular}

Neste delineamento foram considerados como variáveis independentes a umidade e a temperatura e os intervalos entre os niveis foram: $d_{1}=3 \%$ e $d_{2}=10^{\circ} \mathrm{C}$, com a rotação da rosca mantida constante em 200 rpm (Tabela 5). 
No experimento $E_{2}$, apesar do aumento da região estudada para umidade, houve manutenção do ponto central, com a razão de expansão mostrando-se semelhante às anteriores e os extremos de umidade prejudiciais à expansão.

Tabela 6: Análise de regressão múltipla para o modelo de Segunda ordem da variável razão de expansão $(Y)\left(E_{2}\right)$

\begin{tabular}{lccc}
\hline \multicolumn{1}{c}{ Fonte de variação } & Coeficiente & t-estimativa & Nivel de significância \\
\hline Constante & 3,826667 & 92,1030 & 0,0000 \\
$x_{1}$ (umidade) & 0,018447 & 0,5127 & 0,6220 \\
$x_{2}$ (temperatura) & $-0,038247$ & $-1,0630$ & 0,3188 \\
$x_{1}{ }^{2}$ & $-0,117084$ & $-3,1263$ & 0,0141 \\
$x_{2}{ }^{2}$ & 0,015417 & 0,4117 & 0,6914 \\
$x_{1} x_{2}$ & $-0,1025$ & $-2,0143$ & 0,0787 \\
\hline
\end{tabular}

Tabela 7: Análise de variância para razão de expansão $\left(E_{2}\right)$

\begin{tabular}{lllllll}
\hline & $\begin{array}{c}\text { Soma de } \\
\text { quadrados }\end{array}$ & $\begin{array}{c}\text { Grau de } \\
\text { liberdade }\end{array}$ & $\begin{array}{c}\text { Média } \\
\text { quadrática }\end{array}$ & $\begin{array}{c}\text { F- } \\
\text { calculado }\end{array}$ & $\begin{array}{c}\text { P-nivel de } \\
\text { significância }\end{array}$ & $\begin{array}{c}\text { F-tabelado } \\
(5 \%)\end{array}$ \\
\hline Modelo & 0,162113 & 5 & 0,0324227 & 3,13043 & 0,0737 & 3,69 \\
Erro & 0,0828581 & 8 & 0,0103573 & & & \\
\hline
\end{tabular}

Total (corr) $\quad 0,244971 \quad 13$

$$
R^{2}=0,6618
$$

Após a análise de regressão múltipla verificou-se uma melhora da resposta ao modelo, que apesar de pouco satisfatória, apresentou $\mathrm{R}^{2}$ superior a $66 \%$ (Tabela 7). A equação preditiva resultante considerou significativo o efeito quadrático da umidade $\left(x_{1}{ }^{2}\right)$ e a interação entre temperatura e umidade $\left(x_{1} x_{2}\right)$ :

$$
Y=3,83-0,12 x_{1}-0,10 x_{1} x_{2}
$$


Apesar da melhora na resposta ao modelo, a análise sensorial informal dos snacks demonstrou que condições extremas, ou seja, temperaturas muito altas com umidades baixas ou umidades altas com temperaturas baixas, produzem snacks pouco aceitáveis, devido ao aumento na fragilidade e ao sabor tostado dos produtos obtidos.

O terceiro delineamento $\left(E_{3}\right)$ adotado foi:

Tabela 8: Delineamento experimental $\left(E_{3}\right)$ e razão de expansão obtidos em função da umidade da amostra e temperatura de extrusão.

\begin{tabular}{lllllc}
\hline Ensaios & \multicolumn{2}{c}{$\begin{array}{c}\text { Variáveis } \\
\text { Codificadas }\end{array}$} & \multicolumn{2}{c}{$\begin{array}{c}\text { Variáveis } \\
\text { Originais }\end{array}$} & $\begin{array}{c}\text { Razão de } \\
\text { expansão }\end{array}$ \\
& \multicolumn{1}{c}{$\mathrm{X}_{1}$} & \multicolumn{1}{c}{$\mathrm{x}_{2}$} & $\mathrm{X}_{1}$ & $\mathrm{X}_{2}$ & $\mathrm{X}( \pm \mathrm{DP})$ \\
\hline 1 & -1 & -1 & 9 & 140 & $2,71 \pm 0,34$ \\
2 & -1 & 1 & 9 & 160 & $3,63 \pm 0,48$ \\
3 & 1 & -1 & 17 & 140 & $3,67 \pm 0,30$ \\
4 & 1 & 1 & 17 & 160 & $3,01 \pm 0,35$ \\
5 & 0 & 0 & 13 & 150 & $3,73 \pm 0,38$ \\
6 & 0 & 0 & 13 & 150 & $3,78 \pm 0,33$ \\
7 & 0 & 0 & 13 & 150 & $3,37 \pm 0,22$ \\
8 & 1,41421 & 0 & 18,66 & 150 & $3,17 \pm 0,30$ \\
9 & $-1,41421$ & 0 & 7,34 & 150 & $2,86 \pm 0,43$ \\
10 & 0 & 1,41421 & 13 & 164,14 & $3,64 \pm 0,35$ \\
11 & 0 & $-1,41421$ & 13 & 135,8 & $3,52 \pm 0,30$ \\
12 & 0 & 0 & 13 & 150 & $3,35 \pm 0,22$ \\
13 & 0 & 0 & 13 & 150 & $3,78 \pm 0,33$ \\
14 & 0 & 0 & 13 & 150 & $3,67 \pm 0,38$ \\
\hline
\end{tabular}


O terceiro delineamento manteve as variáveis independentes, alterando apenas o intervalo de variação para umidade $d_{1}=4 \%$ (Tabela 8). Esta ampliação da faixa de variação da umidade foi proposta a fim de estabelecer um novo ponto central, bem como pesquisar extremos para esta variável, verificando a capacidade máxima e mínima do equipamento utilizado. Diferentemente dos ensaios anteriores, o ponto central teve uma diminuição na expansão, porém com valores constantes. Quanto aos extremos, a resposta foi menos satisfatória ainda.

Tabela 9: Análise de regressão múltipla para o modelo de Segunda ordem da variável razão de expansão $(Y)\left(E_{3}\right)$

\begin{tabular}{lccc}
\hline \multicolumn{1}{c}{ Fonte de variação } & Coeficiente & t-estimativa & Nivel de significância \\
\hline Constante & 3,613333 & 55,0528 & 0,0000 \\
$x_{1}$ (umidade) & 0,097301 & 1,7118 & 0,1253 \\
$x_{2}$ (temperatura) & 0,053713 & 0,9450 & 0,3723 \\
$x_{1}{ }^{2}$ & $-0,309793$ & $-5,2364$ & 0,0008 \\
$x_{2}{ }^{2}$ & $-0,027291$ & $-0,4613$ & 0,6569 \\
$x_{1} x_{2}$ & $-0,395$ & $-4,9139$ & 0,0012 \\
\hline
\end{tabular}

Tabela 10: Análise de variância para razão de expansão $\left(E_{3}\right)$

\begin{tabular}{lllllll}
\hline & $\begin{array}{c}\text { Soma de } \\
\text { quadrados }\end{array}$ & $\begin{array}{c}\text { Grau de } \\
\text { liberdade }\end{array}$ & $\begin{array}{c}\text { Média } \\
\text { quadrática }\end{array}$ & $\begin{array}{c}\text { F- } \\
\text { calculado }\end{array}$ & $\begin{array}{c}\text { P-nivel de } \\
\text { significancia }\end{array}$ & $\begin{array}{c}\text { F-tabelado } \\
(5 \%)\end{array}$ \\
\hline Modelo & 1,43172 & 5 & 0,286344 & 11,0785 & 0,0020 & 3,69 \\
Erro & 0,206775 & 8 & 0,0258469 & & & \\
\hline
\end{tabular}

Total (corr.) $1,63849 \quad 13$

$$
R^{2}=0,8738
$$


$\mathrm{Na}$ análise de variância, os resultados indicaram que o efeito quadrático da umidade e o efeito da interação foram significativos (Tabela 9). A equação preditiva resultante foi:

$$
Y=3,61-0,31 x_{1}^{2}-0,40 x_{1} x_{2}
$$

Apesar do efeito linear e quadrático da temperatura não apresentarem significância para o modelo, do ponto de vista sensorial, o excesso de temperatura provocou alteração na textura do produto.

A análise sensorial informal do produto mostrou que os snacks apresentaram maior fragilidade à mordida com sabor de queimado em alguns pontos do delineamento, e alta resistência à mordida com sabor de farinha crua em outros. Neste delineamento houve melhor ajuste do modelo $\left(R^{2}>0,87\right)$ (Tabela 10), fazendo-se necessário um deslocamento no ponto central, para melhorar a expansão do produto.

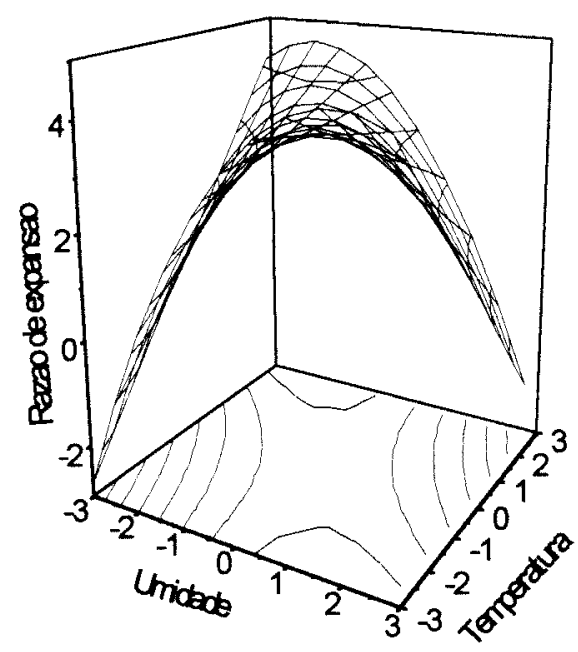

Figura 8: Superfície de resposta do extrusado de milho para razão de expansão em função da umidade e temperatura $\left(E_{3}\right)$ 
No experimento subsequente $\left(E_{4}\right)$ o deslocamento do ponto central foi a principal alteração. As variáveis estudadas foram mantidas com um deslocamento do ponto central para $17 \%$ de umidade e $160^{\circ} \mathrm{C}$ de temperatura e intervalos de variação entre os niveis mantidos em $d_{1}=4 \%$ e $d_{2}=10^{\circ} \mathrm{C}$.

Após análise de regressão, considerou-se significativo o efeito linear $e$ quadrático da umidade $\left(R^{2}>0,83\right)$. Além disso, a temperatura associada a este fator demonstrou melhora nas caracteristicas texturais, com snacks mais expandidos e crocantes à partir de $13 \%$ de umidade e $170^{\circ} \mathrm{C}$.

A equação preditiva para este experimento $\left(E_{4}\right)$ foi:

$$
Y=3,56-0,28 X_{1}-0,15 X_{1}^{2}
$$

A superficie de resposta apresentada (Figura 9) demonstrou um máximo de expansão em $13 \%$ de umidade. Para um novo delineamento foi proposto um estreitamento da faixa de variação para umidade, bem como o aumento e ampliação das temperaturas empregadas. 


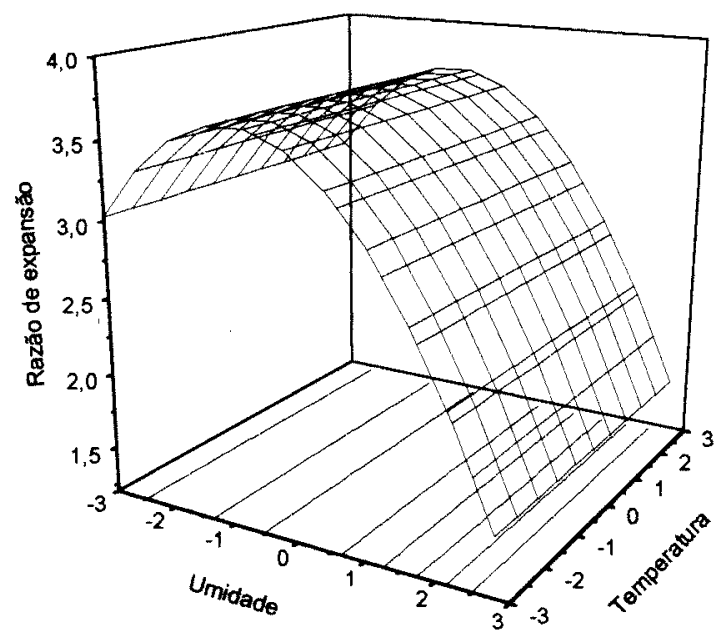

Figura 9: Superfície de resposta do extrusado de milho para razão de expansão em função da umidade e temperatura $\left(E_{4}\right)$

No quinto experimento $\left(E_{5}\right)$, foi mantido o delineamento com um deslocamento do ponto central para $13 \%$ de umidade e $150^{\circ} \mathrm{C}$ de temperatura com a ampliação dos intervalos de variação para temperatura $\left(d_{2}=15^{\circ} \mathrm{C}\right)$. O experimento proposto não permitiu a obtenção de respostas, uma vez que as condições extremas ( $9 \%$ de umidade e $135^{\circ} \mathrm{C}$ de temperatura) inviabilizaram a produção no equipamento.

Apesar de processos de otimização eliminarem a exaustiva tarefa de modificar cada uma das variáveis independentemente e avaliarem as interações que são normalmente ignoradas em experimentos isolados (GARCIA et al 1999), a pesquisa das variáveis em ordem crescente de temperaturas e rotação da rosca mostrou-se necessária. 
0 processo de extrusão pode ser dividido em duas categorias. A primeira, também conhecida como extrusão a frio, transforma a matéria-prima em um extrusado homogêneo, porém não cozido, que é transportado pela pressão gerada no parafuso contra o orificio de saida. Neste grupo estão incluidas as massas para produção de biscoitos doces e tortas. O segundo, chamado de extrusão termoplástica, como o nome já diz, processa as matérias-primas por uma ação combinada de calor, cisalhamento mecânico e pressão (acima de $250^{\circ} \mathrm{C}$ e $25 \mathrm{MPa}$ ). A massa resultante desse processo pode ser homogênea ou heterogênea (p.e., proteinas e carboidratos termodinamicamente incompativeis) e será convertida para um estado elástico e finalmente amorfo-vitreo no resfriamento ou secagem. Simultaneamente, a expansão no orifício de saida ocorre devido às propriedades viscoelásticas da matéria fundida e da evaporação da água causando uma expansão anisotrópica, ou seja, em extensão diferente nas várias direções, fornecendo uma estrutura porosa ao produto.

Em ambos, os atributos finais do produto são controlados pela manipulação do input de energia térmica ou mecânica e o tempo de residência do produto, os quais são determinados por variáveis como umidade do material, temperatura de extrusão, velocidade de rotação e configuração da rosca (RISVI et al 1995).

Na maioria dos experimentos com extrusão, as matérias-primas apresentam menos que $35 \%$ de umidade e a massa formada apresenta comportamento usualmente não-Newtoniano. Além disso, a temperatura, a composição química, o tempo e o conteúdo de umidade alteram a viscosidade. HARPER (1979) descreveu as relações existentes entre a geometria da extrusora e as propriedades associadas à fluidez do produto como a razão do fluxo, a mudança de pressão e o gasto de energia. No interior da extrusora é desejado um fluxo estável, com comportamento Newtoniano, entretanto, a maioria dos alimentos não apresenta 
esse comportamento, sendo a massa formada, durante o processo, pseudoplástica, ou seja, a matéria granular introduzida no equipamento após o aquecimento e cisalhamento intemo é transformada em uma massa com características plásticas devido a gelatinização do amido contido nas amostras.

Estudos realizados com gritz de milho puro e adicionados de materiais protéicos de origem animal demonstraram que a umidade apresenta grande correlação com a capacidade de alimentação, estando atrelada a outras variáveis estudadas (temperatura e rotação da rosca) durante a extrusão. Este parâmetro pode ser considerado o mais crítico do processo, onde umidade elevada e baixa temperatura promovem a máxima gelatinização do amido contido no produto e viceversa, atribuindo à água a capacidade de atuar como lubrificante que permite a manutenção ou interrupção do fluxo para a saida do extrusor (RHEE et al 1999; MERCIER e FEILLET 1975; LAWTON et al 1972). Outros estudos demonstram a relação da velocidade da rotação da rosca, taxa de compressão e conteúdo de umidade de gritz de milho com a velocidade do fluxo no interior do equipamento, demonstrando um aumento linear do fluxo com o aumento da velocidade de rotação da rosca (HARMANN e HARPER 1974).

As características reológicas do produto estudado e as condições de extrusão necessárias para obtenção de um fluxo contínuo do material no interior do equipamento demonstraram a possibilidade de inclusão da rotação da rosca como variável independente. O milho, após aquecimento no interior da extrusora, apresenta características pseudoplásticas, desde que haja tempo suficiente para sua completa gelatinização. Nos delineamentos propostos, a adoção de umidade e temperatura limitrofes para o equipamento caracterizaram o material na saida do equipamento como dilatante. O fato de estabelecer o máximo de rotação, como uma variável fixa para o processo associado às características reológicas descritas 
acima, impede que o material, ao se aproximar da saida, mantenha um fluxo constante e ordenado com consequente obstrução do equipamento. Para tal, rotações variadas com temperaturas crescentes permitiram um fluxo contínuo e maior expansão, como visto na tabela 11.

O teste adotou três variáveis independentes: umidade, temperatura e rotação da rosca com variações de $2 \%, 10^{\circ} \mathrm{C}$ e $20 \mathrm{rpm}$, respectivamente. Os pontos centrais ficaram estabelecidos em $13 \%$ de umidade, $160^{\circ} \mathrm{C}$ de temperatura (zona 3 ) e $120 \mathrm{rpm}$ de rotação da rosca. A temperatura da zona 2 permaneceu $30^{\circ} \mathrm{C}$ abaixo da zona 3 e na zona 1 a temperatura foi mantida fixa em $80^{\circ} \mathrm{C}$. 
Tabela 11: Valores de umidade, rotação da rosca, temperatura e razão de expansão de gritz de milho

\begin{tabular}{|c|c|c|c|c|c|c|}
\hline \multirow[t]{2}{*}{ Ensaios } & \multicolumn{3}{|c|}{ Temperaturas $\left({ }^{\circ} \mathrm{C}\right)$} & \multirow{2}{*}{ Umidade } & \multirow{2}{*}{$\begin{array}{c}\text { Rotação } \\
\text { da } \\
\text { rosca }\end{array}$} & \multirow{2}{*}{$\begin{array}{l}\text { Razão de } \\
\text { expansão } \\
X( \pm D P)\end{array}$} \\
\hline & Zona 1 & Zona 2 & Zona 3 & & & \\
\hline 1 & 85 & 140 & 170 & 15 & 70 & $3,73 \pm 0,43$ \\
\hline 2 & 95 & 150 & 180 & 15 & 70 & $3,52 \pm 0,35$ \\
\hline 3 & 70 & 120 & 150 & 15 & 70 & $3,93 \pm 0,60$ \\
\hline 4 & 70 & 120 & 150 & 13,8 & 70 & $4,05 \pm 0,59$ \\
\hline 5 & 70 & 120 & 150 & 15 & 70 & $3,50 \pm 0,50$ \\
\hline 6 & 70 & 120 & 150 & 15 & 50 & $3,36 \pm 0,44$ \\
\hline 7 & 100 & 160 & 190 & 15 & 70 & $3,35 \pm 0,38$ \\
\hline 8 & 85 & 140 & 170 & 15 & 70 & $3,62 \pm 0,65$ \\
\hline 9 & 85 & 140 & 170 & 15 & 60 & $3,69 \pm 0,49$ \\
\hline 10 & 85 & 140 & 170 & 15 & 80 & $3,86 \pm 0,35$ \\
\hline 11 & 85 & 140 & 170 & 15 & 100 & $3,83 \pm 0,34$ \\
\hline 12 & 85 & 140 & 170 & 15 & 120 & $3,67 \pm 0,48$ \\
\hline 13 & 85 & 140 & 170 & 15 & 150 & $3,77 \pm 0,25$ \\
\hline 14 & 85 & 140 & 170 & 15 & 170 & $4,03 \pm 0,55$ \\
\hline 15 & 85 & 140 & 170 & 15 & 190 & $3,72 \pm 0,37$ \\
\hline 16 & 85 & 140 & 170 & 15 & 50 & $3,59 \pm 0,61$ \\
\hline
\end{tabular}

Após estes testes, foi estabelecido que a rotação da rosca seria uma variável importante de estudo. Para sua verificação foi realizado um experimento incluindo a rotação da rosca como variável independente, juntamente com a umidade e temperatura que já estavam sendo estudadas. Neste teste, a temperatura da região final do canhão passou a ser considerada como variável independente, na tentativa de estabilizar o processo, associado a menor rotação da rosca. Baseado nos dados da tabela 11 , foi estabelecido $13 \%, 160^{\circ} \mathrm{C}$ e $120 \mathrm{rpm}$ com variações de $2 \%, 10^{\circ} \mathrm{C}$ e 20 rpm para umidade, temperatura e rotação da rosca, respectivamente. 
O sexto delineamento $\left(E_{6}\right)$ adotado incluiu novamente a rotação da rosca como variável resposta e é mostrado na Tabela 12.

Tabela 12: Delineamento experimental $\left(E_{6}\right)$ e razão de expansão obtidos em função da umidade da amostra, temperatura de extrusão e rotação da rosca

\begin{tabular}{|c|c|c|c|c|c|c|c|}
\hline \multirow[t]{2}{*}{ Ensaios } & \multicolumn{3}{|c|}{ Variáveis Codificadas } & \multicolumn{3}{|c|}{ Variáveis Originais } & \multirow{2}{*}{$\begin{array}{c}\text { Razão de } \\
\text { expansão } \\
X( \pm D P)\end{array}$} \\
\hline & $\begin{array}{c}x_{1} \\
(U-13) / 2\end{array}$ & $\begin{array}{c}x_{2} \\
(T-160) / 10\end{array}$ & $\begin{array}{c}X_{3} \\
(R-120) / 20\end{array}$ & $\begin{array}{l}X_{1} \\
(U)\end{array}$ & $\begin{array}{l}X_{2} \\
(T)\end{array}$ & $\begin{array}{l}X_{3} \\
(R)\end{array}$ & \\
\hline 1 & -1 & -1 & -1 & 11 & 150 & 100 & $4,16 \pm 0,42$ \\
\hline 2 & -1 & 1 & 1 & 11 & 170 & 140 & $3,39 \pm 0,68$ \\
\hline 3 & 1 & -1 & 1 & 15 & 150 & 140 & $3,83 \pm 0,37$ \\
\hline 4 & 1 & -1 & -1 & 15 & 170 & 100 & $3,52 \pm 0,46$ \\
\hline 5 & 0 & 0 & 0 & 13 & 160 & 120 & $4,03 \pm 0,40$ \\
\hline 6 & 0 & 0 & 0 & 13 & 160 & 120 & $3,94 \pm 0,37$ \\
\hline 7 & -1 & -1 & 1 & 11 & 150 & 140 & $4,15 \pm 0,41$ \\
\hline 8 & -1 & 1 & -1 & 11 & 170 & 100 & $4,15 \pm 0,32$ \\
\hline 9 & 1 & -1 & -1 & 15 & 150 & 100 & $3,57 \pm 0,51$ \\
\hline 10 & 1 & 1 & 1 & 15 & 170 & 140 & $2,51 \pm 0,89$ \\
\hline 11 & 0 & 0 & 0 & 13 & 160 & 120 & $4,10 \pm 0,37$ \\
\hline 12 & 0 & 0 & 0 & 13 & 160 & 120 & $4,12 \pm 0,25$ \\
\hline 13 & 1,68179 & 0 & 0 & 16,36 & 160 & 120 & $3,94 \pm 0,48$ \\
\hline 14 & $-1,68179$ & 0 & 0 & 9,64 & 160 & 120 & $4,01 \pm 0,26$ \\
\hline 15 & 0 & 1,68179 & 0 & 13 & 176,8 & 120 & $3,81 \pm 0,47$ \\
\hline 16 & 0 & $-1,68179$ & 0 & 13 & 143,2 & 120 & $4,13 \pm 0,35$ \\
\hline 17 & 0 & 0 & 1,68179 & 13 & 160 & 153,6 & $3,14 \pm 0,47$ \\
\hline 18 & 0 & 0 & $-1,68179$ & 13 & 160 & 86,4 & $3,78 \pm 0,46$ \\
\hline 19 & 0 & 0 & 0 & 13 & 160 & 120 & $4,02 \pm 0,48$ \\
\hline 20 & 0 & 0 & 0 & 13 & 160 & 120 & $4,09 \pm 0,28$ \\
\hline
\end{tabular}


Tabela 13: Análise de regressão múltipla para o modelo de Segunda ordem da variável razão de expansão $(Y)\left(E_{6}\right)$

\begin{tabular}{lccc}
\hline \multicolumn{1}{c}{ Fonte de variação } & Coeficiente & t-estimativa & Nivel de significância \\
\hline Constante & 4,046426 & 45,5696 & 0,0000 \\
$x_{1}$ (umidade) & $-0,200751$ & $-2,8373$ & 0,0176 \\
$x_{2}$ (temperatura) & $-0,202603$ & $-3,4010$ & 0,0068 \\
$x_{3}$ (rotação da rosca) & $-0,165111$ & $-2,7716$ & 0,0197 \\
$x_{1}{ }^{2}$ & $-0,013253$ & $-0,1957$ & 0,8487 \\
$x_{2}{ }^{2}$ & $-0,063911$ & $-1,1018$ & 0,2963 \\
$x_{3}{ }^{2}$ & $-0,261901$ & $-4,5152$ & 0,0011 \\
$x_{1} x_{2}$ & $-0,08689$ & $-0,9211$ & 0,3787 \\
$x_{1} x_{3}$ & $-0,001524$ & $-0,0162$ & 0,9874 \\
$x_{2} x_{3}$ & $-0,24875$ & $-3,2157$ & 0,0092 \\
\hline
\end{tabular}

Tabela 14: Análise de variância para razão de expansão $\left(E_{6}\right)$

\begin{tabular}{lllllll}
\hline & $\begin{array}{c}\text { Soma de } \\
\text { quadrados }\end{array}$ & $\begin{array}{c}\text { Grau de } \\
\text { liberdade }\end{array}$ & $\begin{array}{c}\text { Média } \\
\text { quadrática }\end{array}$ & $\begin{array}{c}\text { F- } \\
\text { calculado }\end{array}$ & $\begin{array}{c}\text { P-nível de } \\
\text { significância }\end{array}$ & $\begin{array}{c}\text { F-tabelado } \\
(5 \%)\end{array}$ \\
\hline Modelo & 2,92699 & 9 & 0,325221 & 0,728753 & 6,79376 & 3,02 \\
Erro & 0,478706 & 10 & 0,0478706 & & & \\
\hline Total (corr) & 3,40570 & 19 & & & &
\end{tabular}

Total (corr.) $3,40570 \quad 19$

$$
R^{2}=0,85944
$$

Neste experimento foram considerados significativos o efeito linear da umidade, da temperatura e da rotação da rosca, o efeito quadrático da rotação da rosca e a interação entre temperatura e rotação da rosca. 
Para tal, a equação preditiva foi:

$Y=4,05-0,20 x_{1}-0,20 x_{2}-0,16 x_{3}-0,26 x_{3}{ }^{2}-0,25 x_{2} x_{3}$

Para efeito de avaliação foram derivadas as equações:

$Y=4,05-0,20 x_{1}-0,20 x_{2}(1)$

$Y=4,05-0,20 x_{1}-0,16 x_{3}-0,26 x_{3}^{2} \quad(2)$

$Y=4,05-0,20 x_{2}-0,16 x_{3}-0,26 x_{3}^{2}-0,25 x_{2} x_{3}(3)$

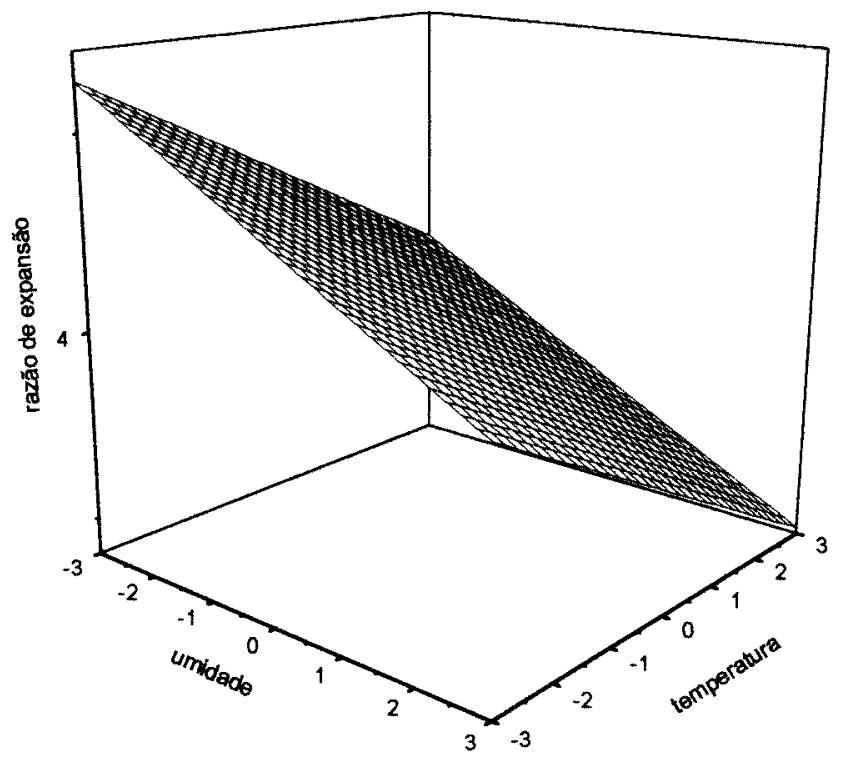

Figura 10: Superficie de resposta do extrusado de milho para razão de expansão em função da umidade e temperatura $\left(E_{6}\right)(1)$ 


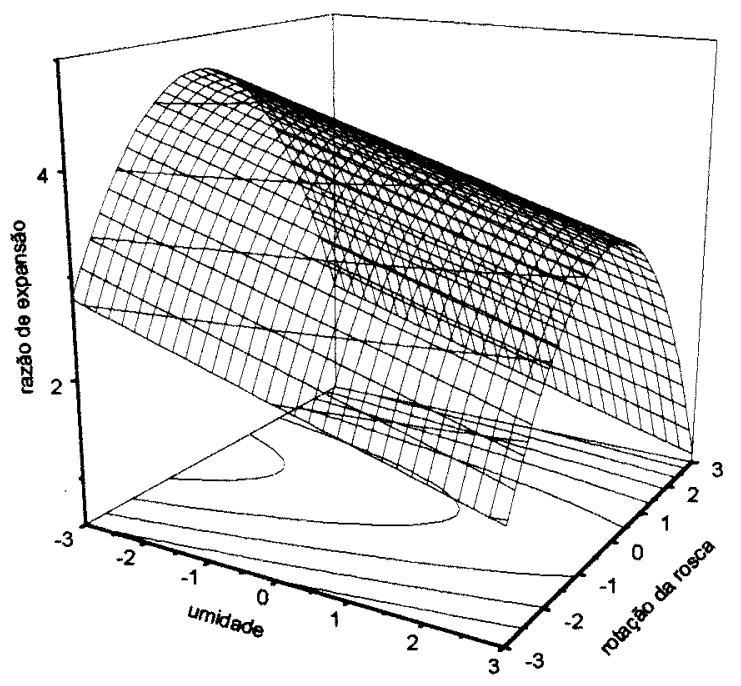

Figura 11: Superfície de resposta do extrusado de milho para razão de expansão em função da umidade e rotação da rosca $\left(E_{6}\right)(2)$

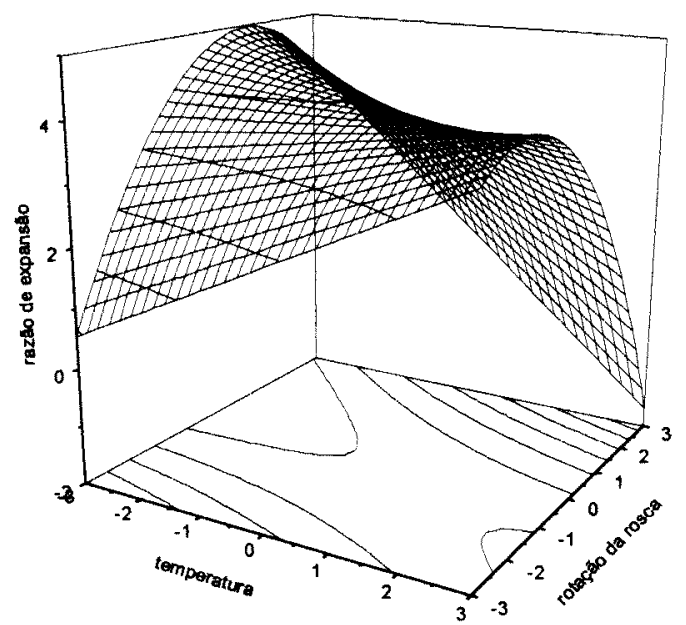

Figura 12: Superfície de resposta do extrusado de milho para razão de expansão em função da temperatura e rotação da rosca $\left(E_{6}\right)(3)$ 
A partir das representações gráficas (Figuras 10-12) e derivando-se a equação do modelo em relação a todas as variáveis (Anexo 5), verificou-se um máximo de expansão em $170^{\circ} \mathrm{C}$ de temperatura e $104 \mathrm{rpm}$ de rotação da rosca $\left(\frac{\partial y}{\partial x_{2}}=\frac{\partial y}{\partial x_{3}}=0\right)$. valor para umidade não pôde ser determinado a partir da derivada pois não máximos ou mínimos $\left(\frac{\partial y}{\partial x_{1}} \neq 0\right)$ para essa função. Entretanto, a partir da observação da superfície apresentada (Figura 10), verificou-se que o máximo de expansão foi obtido em umidade baixa (11\%) com tendência a aumento da resposta a medida que se diminui os valores de umidade. Isto obviamente será limitado pela capacidade de operação do equipamento. Baixas umidades requerem progressivamente mais cisalhamento, até um limite dado pelo torque do acionamento.

Em todos os experimentos, verificamos a significância do efeito quadrático da umidade na variável resposta razão de expansão. Entretanto, no experimento $E_{6}$ apenas o efeito linear da umidade foi observado devido talvez a inclusão da variável rotação da rosca, que se mostrou significativa nesse delineamento.

Os dados indicam que nas faixas estudadas, houve um bom ajuste do modelo com $R^{2}>0,85$. Após este experimento considerou-se o processo otimizado sendo necessário um ajuste apenas para produção em maior escala. 


\subsection{Produção em larga escala}

A fim de realizar a intervenção foi necessário adaptar as condiçōes de extrusão para uma escala maior em equipamento com capacidade de produção superior a $20 \mathrm{~kg}$ de snack/hora (modelo Inbra 120, INBRAMAQ - Indústria de Máquinas Ltda, Ribeirão Preto-SP).

Os snacks obtidos neste equipamento apresentaram uma expansão semelhante a obtida na otimização do processo. A razão de expansão obtida para o milho foi de $4,14 \pm 0,51$ e da mistura pulmão bovino foi de $3,63 \pm 0,66$. Para força de cisalhamento, o milho apresentou $44,38 \mathrm{~N} \pm 8,1$ e da mistura pulmão bovino foi de $37,71 \mathrm{~N} \pm 8,27$

No equipamento de produção em larga escala empregado, a maior geração de energia se dá pela pela força de atrito exercida no material, em função da configuração da rosca e camisa, associada a umidade do material presente, dispensando assim temperaturas muito elevadas, como na produção laboratorial. Associado a este parâmentro, a umidade excerce um efeito muito significativo no produto extrusado onde verifica-se que em umidades muito baixas a geração de calor também é elevada devido ao cisalhamento interno que favorece à expansão do produto (HARPER 1979). 


\subsection{Análise sensorial}

Foi realizado teste de aceitação dos snacks produzidos em larga escala pelas crianças potencialmente consumidoras do snack. Para tal foi selecionada uma população de crianças e adolescentes variando de 6 a 15 anos, de ambos sexos, frequentadoras do Centro da Juventude Paulo de Tarso, em São Paulo-SP. O CJ é conveniado à Prefeitura de São Paulo e as crianças e adolescentes que frequentam - local estudam ou moram nos arredores. Sua permanência é no período vespertino onde recebem reforço escolar, apoio psicológico quando necessário e realizam atividades esportivas e lúdicas. São oferecidas duas refeições durante o periodo, incluindo o almoço e o lanche, sendo as análises realizadas no intervalo entre elas procurando respeitar o intervalo de duas horas após a refeição.

A população do CJ foi convidada a participar de duas sessões de análise sensorial em dias diferentes. Em cada data foi oferecido às crianças um tipo de snack, milho e milho com pulmão bovino, com a participação de 83 e 84 crianças, respectivamente. Para avaliação foi utilizada uma escala hedônica facial de cinco pontos (Anexo 1)

A distribuição da população para sexo mostrou-se bastante homogênea com 47 e $48 \%$ de meninas e 53 e $52 \%$ de meninos para snacks de milho e milho com pulmão bovino, respectivamente.

A nota média de aceitação foi de 4,9 para snacks de milho e 4,6 para os de milho e pulmão bovino. A distribuição das notas (\%), encontra-se na Figura 13. 


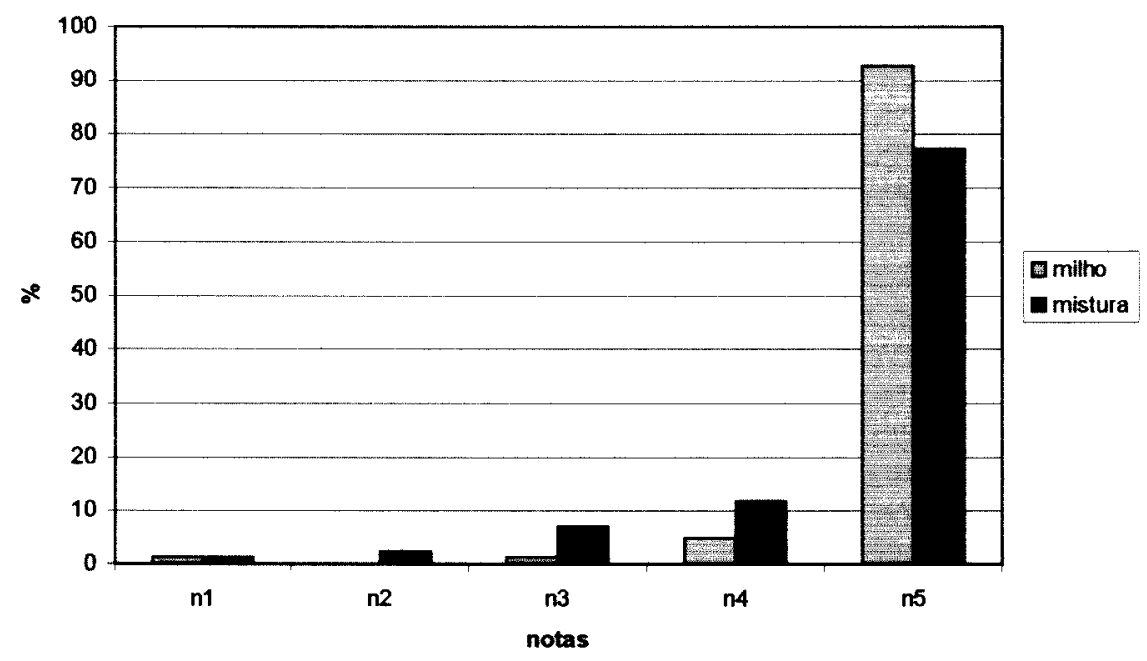

Figura 13: Distribuição (\%) das notas dadas aos snacks de milho e mistura de milho/pulmão bovino

A maioria (89\%) dos provadores apresentaram uma boa aceitação para o produto adicionado de pulmão bovino contra uma pequena minoria (4\%) que apresentaram rejeição ao snack. Quando avaliado por faixa etária (Figuras 14 e 15), percebe-se uma tendência à seletividade no produto adicionado de pulmão bovino. O grupo de 12 a 15 apresenta maior distribuição entre as notas 4 e 5 porém, com a maioria de aceitação acima da nota quatro $(79 \%)$ e aproximadamente $20 \%$ se mostrando indiferentes ao snack (nota 3 ). 


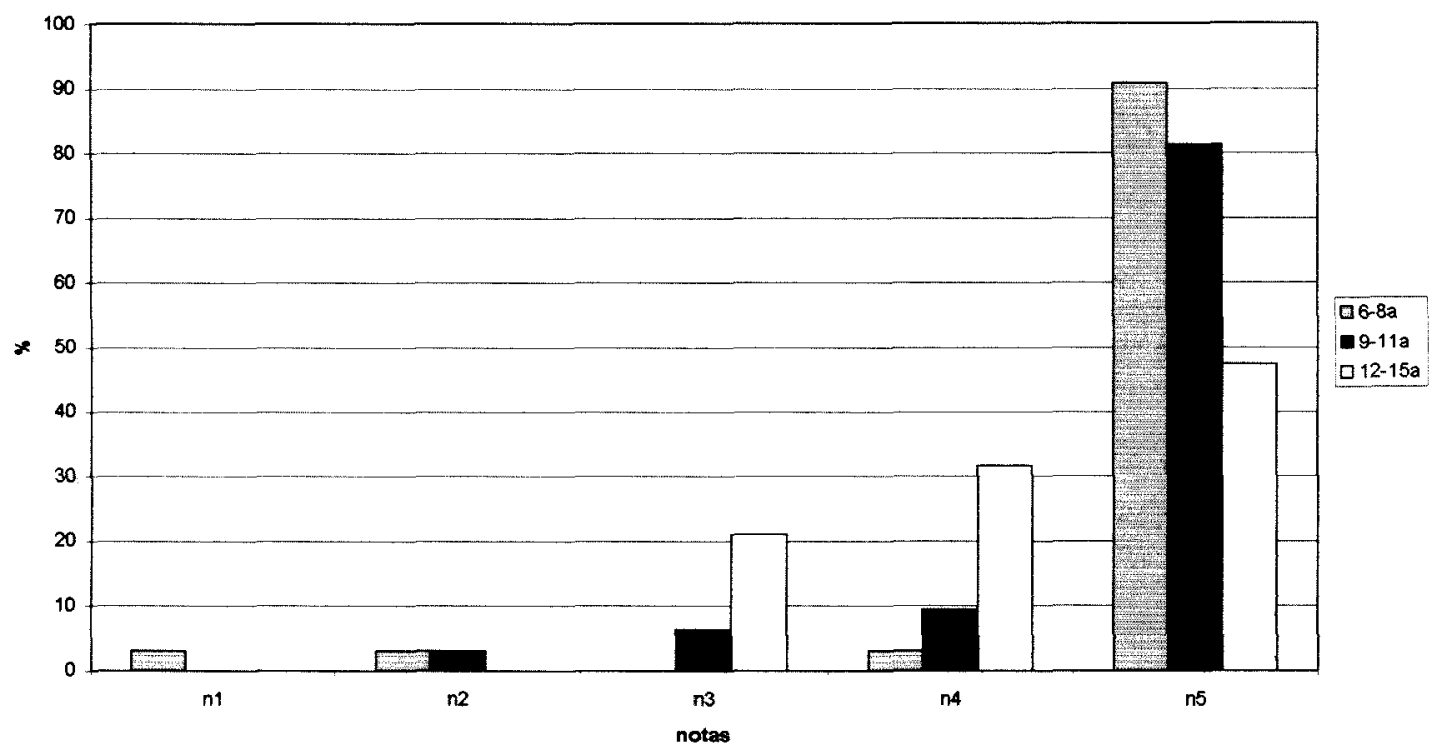

Figura 14: Distribuição (\%) das notas dadas ao snack de milho e pulmão bovino segundo idade

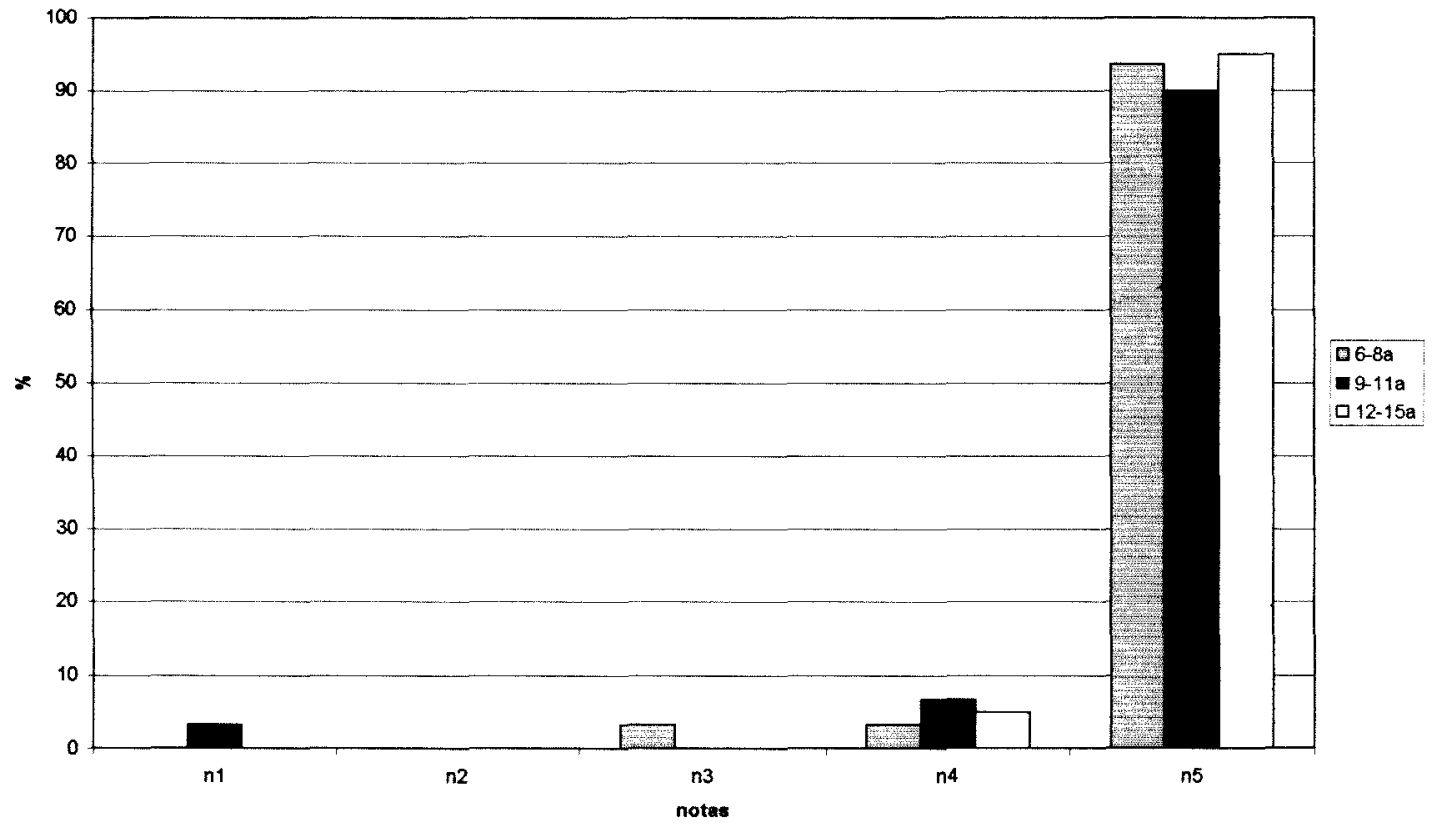

Figura 15: Distribuição (\%) das notas dadas ao snack de milho segundo idade 
Para a comparação das médias de aceitação foi realizado o teste de Tukey e verificou-se que as médias são iguais entre si a um nivel de significância de $5 \%$. Os dados apresentados mostraram-se semelhantes a um estudo realizado com adição de diferentes tipos de carnes ao amido de milho (RHEE et al 1999).

Quando comparado ao snack comercial, verificou-se uma redução no conteúdo de gordura e consequente valor calórico total. Diante disto, os snacks desenvolvidos no presente trabalho podem ser produzidos industrialmente com a vantagem do baixo teor de gordura, associado ao aumento do conteúdo de ferro e proteinas. 


\section{CONCLUSÕES}

No processo de otimização de extrusão para misturas de milho e pulmão bovino (90:10), o melhor snack foi obtido em $11 \%$ de umidade, $170^{\circ} \mathrm{C}$ de temperatura e 104 rpm de rotação da rosca.

A aceitabilidade do produto mostrou-se bastante elevada (89\%) com a nota média de 4,9 para snacks de milho e 4,6 para snacks de milho com pulmão bovino, numa escala de 5 pontos.

O alimento produzido apresenta elevado conteúdo de ferro biodisponivel, sendo capaz de formecer de $25-15 \%$ das necessidades diárias de ferro para crianças e adolescentes, respectivamente. 


\section{REFERÊNCIAS BIBLIOGRÁFICAS}

ABIMILHO - Associação Brasileira das indústrias de milho. 2001. Disponivel em <URL:http://uww. abimilho.com.br>.

Aguilera JM, Kosikowiski FV. Soybean extruded product: a response surface analysis. J Food Sci 1976; 41: 647-651.

Alcocer MJC, Arêas JAG. Lipid composition and hydration characteristics of lung protein isolates deffated by several solvents. J Food Sci 1990; 55: 19-22.

Almeida-Dominguez, Valencia ME, Higuer-Ciapara I. Formulation of corn-based snacks with high nutritive value: biological and sensory evaluation. J Food Sci 1990; 55 (1): 228-231.

Antilla R, Cook JD, Siimes MA. Body iron stores in relation to growth and puberal maturation in healthy boys. Br. J. Hamematol 1997; 96: 12-18

Arêas JAG. Lipid protein interactions in offal protein isolates: effect of several solvents on lipid extraction. J Food Sci 1985; 50 (5): 1392-1395, 1398.

Arèas JAG. Effect of lipid protein interections of hydration characteristics of defatted offal protein isolates. J Food Sci 1986a; 51: 880-882.

Areaas JAG. Hydrophobic and eletrostatic interactions on extrusion of protein isolates. J Food Sci 1986b; 51: 1311-1313, 1322.

Arêas JAG, Lawrie RA Effect of lipid-protein interactions on extrusion of offal protein isolates. Meat Sci 1984; 11: 275-299.

Arêas JAG. Extrusion of food proteins. Crit Rev Food Sci Nutr 1992; 32 (4): 365392. 
Ascheri JLR, Carvalho CWP. Caracterizacion fisico-quimica de "snacks" de grits de maiz producidos por extrusion termoplastica. Alimentaria 1996; 96 (273): 87-91.

Asp NG, Bjorck I. The effect of extrusion cooking on nutritional value. In: Zeuthen, P. Cheftel, J. C., Eriksson, C. Jul, M. Leniger, H., Linko, P., Varela, G., Vos, G., eds. Thermal processing and quality of foods. London: Elsevier; 1984. p. 162-167.

Assis AMO. Estado da arte da anemia na adolescencia: distribuição e implicações para saúde. In: Obesidade e Anemia carencial na adolescência: simpósio; 2000 jun 8-9; Salvador (BR). São Paulo: Institudo Danone; 2000. p. 33-46

Association Official Analytical Chemists. Official Methods of Analysis. Washington; 1990. p. 1098-99.

Barros RMC, Silva RSF, Borsato D, Arêas JAG. Otimização das condiçōes de extrusão de farelo de soja pelo emprego de Metodologia de Superficie de Resposta. Bol. Centro Pesq Proces Aliment. 1987;5 (2): 61-68.

Barros-Neto B, Sacarminio IS, Bruns RE. Planejamento e otimização de experimentos. Campinas: Ed da UNICAMP; 1995.

Bastos DHM, Arêas JAG. Lung protein: effect of defatting with several solvents and extrusion cooking on some functional properties. Meat Sci. 1990; 28: 223-235.

Bastos DHM, Domenech CR, Arêas JAG. Otimization of extrusion cooking of lung proteins by response surface methodology. Int J Food Sci Technol 1991; 26: $403-$ 408.

Bastos E. Guia para cultivo do milho. São Paulo: Icone; 1987. 
Batistuti JP, Barros RMC, Arêas JAG. Optimization of extrusion cooking process for chickpea (Cicer arietinum, L.) defatted flour by response surface methodology. $J$ Food Sci 1991; 56 (6): 1695-1698.

Baynes RD, Bathwell TH. Iron Defficiency. Ann Rev Nutr 1990; 10: 133-148.

Box GEP, Draper NR. Empirical model-building and response surfaces. New York: John Wiley; 1987.

Bruner AB, Joffe A, Duggan AK, Casella JF, Brandt J. Randomised sudy of cognitive effects of iron supplementation in non-anemic iron-deficient adolescent girl. The Lancet 1996; 348: 992-996.

Camire ME, Camire A, Krumhar K. Chemical and nutritional changes in foods during extrusion. Crit Rev Food Sci Nutr 1990; 19 (1): 35-57.

Campos MA, Arêas JAG. Protein nutritional value of extrusion-cooking defatted lung flour. Food Chem 1993; 47: 61-66.

Cardoso-Santiago RA, Arêas JAG. Nutritional evaluation of snacks obtained from chickpea and bovine lung blends. Food Chem 2001; 74: 35-40.

Cardoso-Santiago RA, Moreira-Araújo RSR, Pinto e Silva MEM, Arêas JAG. The potential of extruded chickpea, com and bovine lung for malnutrition programs. Innovative Food Science \& Emerging Technologies 2001; 2: 203-209.

Cassar R. Efeito da adição de glutamato monossódico e inosinato dissódico no sabor e textura de extrusados à base de grão-de-bico, pulmão bovino e amaranto. São Paulo; 2000. [Dissertação de Mestrado-Faculdade de Saúde Pública da USP] 
Chaud MV, Freitas O. Compostos alternativos para o tratamento e/ou prevenção da anemia ferropriva. Cad Nutr 1994; 8: 1-9.

Chávez-Jáuregui RN, Pinto e Silva MEM, Arêas, JAG. Extrusion cooking process for amaranth (Amaranthus caudatus L). J Food Sci 2000; 65: 1009-1015.

Cheftel, JC. Nutritional effects of extrusion-cooking. Food Chem 1986; 20: 263-283.

Colonna P, Tayeb J, Mercier C Extrusion cooking of starch and starchy products. In: Mercier P, Linko P, Harper JM, eds. Extrusion cooking. St Paul: American Association of Cereal Chemists; 1989. p. 247-319.

Conti AC, Arêas JAG. Aproveitamento do rúmen bovino na alimentação humana através da sua extrusão termoplástica. Nutrire 2001; 22: 21-31.

Cook JD, Baynes, RD, Skikne, BS. Iron deficiency and the measurement of iron status. Nutr Res Rev 1992; 5: 189-202.

Coulter L A, Lorenz K. Extruded corn grits-quinoa blends: I. Proximate composition, nutritional properties and sensory evaluation. J Food Proces and Preserv 1991; $15: 231-242$.

Dallman PR. Iron deficiency and immune response. Am J Clin Nutr 1987; 46: 32934.

DeMaeyer EM, Dallman P, Gurney JM, Hallberg L, Sood SK, Srikantia SG. Preventing and controlling iron deficiency anaemia through primary health care: a guide for health administration and program managers. Geneva, World Health Organization; 1989. 58 p. 
Dixon JM. Extrusion cooking: a hot technology. Food Eng Int 1983; 6(6): 34-38.

Dziezak JD. Taking the gamble out of product development. Food tech 1990; 44 (6): $110-117$.

El-Dash AA, Gonzales R, Ciol M. Response surface methodology in the control of thermoplastic extrusion of starch. In: Jowitt R, ed. Extrusion cooking technology. London: Elsevier Applied Science; 1984. p. 51-74.

Expert Scientific Working Group. Summary of a report on assessment of iron nutritional status of the United States population. Am J Clin Nutr 1985; 42: 13181330.

FAO EI maiz en la alimentacion: estudio sobre su valor nutritivo. Roma: Nutrition Division; 1954.

FAO/OMS. Necesidades de vitamina A, hierro, folato y vitamina B12. Informe de uma consulta mixta de Expertos. Roma: FAO/OMS; 1991.

Freire WB. Strategies of the Pan American Health Organization / World Health Organization for the control of iron deficiencyin Latin America. Nutr Rev 1997; 55 (6): $183-188$.

Gácula MC, Shign J. Statistical methods in food and consumer research. Orlando: Academic Press; 1984. 505 p.

Garcia T, Sanchez N, Martinez M, Aracil, J. Enzymatic synthesis od fatty esters Part II. Optimization studies. Enzyme and Microbial Technilogy 1999; 25: 591-597.

Gault NFS, Lawrie RA (1980) Efficiency of protein extraction and recovery from meat industry by-products. Meat Sci 1980; 4: p. 167-190. 
González RJ, De Greef DM, Torres RL, Go Rdo NA. Efectos de algunas variables de extrusuion sobre la harina de maiz. Arch Latinoam Nutr 1987; 37 (3): 578-592.

Guy RCE. The extrusuion revolution. Food Manufac 1985; 1: 26-29.

Guyton AC. Fisiologia Humana. Rio de Janeiro: Guanabara-Koogan; 1988. 564 p.

Hallberg L. Bioavailability of dietary iron in man. Ann Rev Nutr 1981; 1: 123-147.

Harmann DV, Harper JM. Modeling a forming foods extruder. J Food Sci 1974; 39: 1099.

Harper JM. Extrusion of Foods. Boca Raton: Crc Press; 1981. v. 2.

Harper JM. Food extrusion. CRC Crit Rev Food Sci Nutr 1979; 11: 155-215.

Harper JM. Extrusion processing of food. Food Technol 1978; 32 (7): 67-72.

Heuvel EGHM Van Den, Dokkum W Van, Schaafsma G. Methods to measure iron absorption in humans: a review. Food Rev Int 1997; 13 (1): 91-102.

IBGE _ Instituto Brasileiro de Geografia e Estatistica. 2001. Disponivel em <URL:http://unw.ibge.gov.br>.

Instituto Adolfo Lutz. Normas analíticas do Instituto Adolfo Lutz. São Paulo; 1985. v. 1.

Kinsella JE. Texturized proteins: fabrication, flavoring and nutrition. CRC Crit Rev Food Sci Nutr 1978; 10: 147-207.

Lawton BT, Henderson GA, Derlatka EJ. The effects of extruder variables on the gelatinization of corn starch. Can J Chem Eng 1972; 50:168. 
Lins e Silva K. Revisão da literatura. In: NUTTI MR, ed. Enriquecimento e restauração de alimentos com micronutrientes: uma proposta para o Brasil. São Paulo: ILSI Brasil; 2000. P. 15-41.

Lönnerdal B, Dewey KG. Epidemiologia da deficiência de ferro no lactente e na criança. Anais Nestlé 1996; 52: 11-17.

Maga JA. Cereal based snack foods. In: Lorenz KJ, Kulf $\mathrm{K}$, eds. Handbook of cereal science and technology. New York: Mercel Dekker; 1991. p. 793-814.

Mannis JG, Schachter D. Active transport of iron by intestine: features of the twostep mechanism. Am J Physiol 1962; 203: 73-86.

Marchi RP. Viabilidade econômica da produção de "snacks", fortificados com ferro, no controle da anemia ferropriva. São Paulo; 2002 [Trabalho apresentado na disciplina Economia da Alimentação e Nutrição-Faculdade de Economia e Administração da USP]

Matson K. What goes on in the extruder barrel. Cereal Foods World 1982; $27: 207-$ 210.

Mercier C. Nutritional appraisal of extruded foods. Int J Food Sci Nutr 1993; 44: S45-S53.

Mercier C, Feillet P. Modification of carboydrate components by extrusion-cooking of cereal products. Cereal Chem 1975; 52: 283.

Mittal P, Lawrie RA Extrusion studies of mixtures containing certain meat offals: part 2 - textural properties. Meat Sci 1986; 16: 143-160. 
Moraes MAC. Métodos para avaliação sensorial dos alimentos. 5. ed. Campinas: Ed. UNICAMP; 1985.85 p.

Moreira-Araújo RSR, Araújo MAM, Silva AMS, Carvalho CMRG, Arêas JAG. Impacto de salgadinho de alto valor nutritivo na situação nutricional de creches municipais da Teresina-PI. Nutrire-Ver Soc Bras Alim Nutr 2002; 23: 7-21 (in press).

National Research Council. Recommended dietary allowances. Washington: National Academy Press; 1989.

Nutti MR. Enriquecimento e restauração de alimentos com micronutrientes: uma proposta para o Brasil. São Paulo: ILSI Brasil; 2000. 129p.

Organizacion Mundial De La Salud Anemias Nutricionales. Genebra. (OMS Serie de informes tecnicos, 405); 1968.

Origin. [programa de computador]. Northampton: Microcal Inc. Cidade;1997

Özdemir M, Devres O. Analysis of color development during roasting of hazelnuts using resposnse surface methodology. J Food Eng 2000; 45:17-24.

Paiva AA, Rondó PHC, Guerra-Shinohara EM. Parâmetros para avaliação do estado nutricional da ferro. Rev Saúde Publ 2000; 34 (4): 421-6.

Phillips DR. Effect of extrusion cooking on the nutritional quality of plant proteins. In: Phillips, D.R., Finley, J.W. Eds. Protein Quality and the Effects of Processing. Marcel Dekker; 1989. P. 593

Pinto TA, Colli C, Arêas JAG. Effect of processing on iron bioavailabilityof extruded bovine lung. Food Chem 1997; 60 (4): 459-463. 
Pollack S, Kaufmann RM, Crosby WH. Iron absorption: the effect of an iron deficient diet. Science 1964; 144: 1015-6.

Pollit E, Saco-Pollit C, Leibel RL, Viteri FE. Iron deficiency and behavioral development in infants and preschool children. Am J Clin Nutr 1986; 43: 555-65.

Pomeranz Y. Modern cereal science and technology. Washington: $\mathrm{VCH} ; 1987$.

Quintaes KD. Utensilios para alimentos e implicações nutricionais. Rev Nutr 2000; $13(3): 151-156$.

Rhee KS, Cho SH, Pradahn AM. Composition, storage, stability and sensory properties of expanded extrudates from blend of corn starch and goat meat, lamb, mutton, spent fowl meat, or beef. Meat Sci 1999; 52: 135-141.

Rizvi SSH, Mulvaney SJ, Sokhey AS. The combined application of supercritical fluid and extrusion technology. Trends Food Sci Tech 1995; 6: 232-240

Rossen JL, Miller RC. Food extrusion. Food Technol 1973; 27 (8): 46-53.

Roughead ZK, Hunt JR. Adaptation in iron absorption: iron supplementation reduces nonheme-iron absorption from food. Am J Clin Nutr 2000; 72: 982-989.

Sheard NF. Iron deficiency and infant development. Nutr Rev 1994; 52: 137-40.

Silmes MA, Refino C, Dallman PR. Manifestation of iron deficiency at various levels of dietary iron intake. Am J Clin Nutr 1980; 33:570-574.

Silva MAAP, coordenadora. Análise sensorial e instrumental. São Paulo; 2000. [Apostila do curso Análise sensorial e instrumental-Faculdade de Engenharia de Alimentos da UNICAMP]. 
Smith OB. Why extrusion cooking?. Cereal Foods World 1976; 21 (1): 4-6, 8.

Souza SB, Szarfarc SC, Souza JMP. Anemia no primeiro ano de vida em relação ao aleitamento matemo. Rev Saúde Pública 1997; 31 (1): 15-20.

Statgraphics. Statistical Graphics Corporation [programa de computador]. USA: STSC Inc:;1987

Stone H, Sidel JL. Sensory evaluation practices. 2. Ed. San Diego: Academic Press; 1991. $338 \mathrm{p}$.

Swingler GR, Lawrie RA. Mixed protein fibres from meat industry by-products. Meat Sci, 1978; 2: 105-117.

Swingler GR, Neale RJ, Lawrie RA. The nutritive value of protein isolates and fibres from meat industry by-products. Meat Sci 1978; $2: 31-39$.

Szarfarc SC, Stefanini, MLR, Lemer BR. Anemia Nutricional no Brasil. Cad Nutrição 1995; 9: 5-24.

Szarfarc SC, Gambardella AMD, Tudisco ES, Vannucchi H. A avaliação do consumo energético - o uso de curvas padronizadas. Cad Nutr 1994; 7: 47-64.

Taboada H. Rol del hierro en la nutrición infantil - primera parte.Rev Chil Ped 1983; 54: 47-57.

Texture Expert. [programa de computador]. USA: Stable System. Cidade;1999

Torres MAA, Sato K, Lobo NF, Queiroz, SS. Efeito do uso de leite fortificado com ferro e vitamina $C$ sobre os niveis de hemoglobina e condição nutricional de criancas menores de 2 anos. Rev de Saúde Pública 1995; 29 (4): 301-307. 
UNICEF/UNUNHO/MI. Preventing iron deficiency in women and children: background and consensus on key technical issues and resources for advocacy, planning and implementing national programmes. Boston: INF/MI;1999. [UNICEF/UNUMHO/MI Thechnical Workshop; 1998 oct 7-9; New York]

Viteri FE. Iron supplementation for the control of iron deficiency in population at risk. Nutr Rev 1997; 55: 195-209.

Worwood M. Regulação do metabolismo do ferro. Anais Nestlé 1996; 52: 1-10.

Ziegler EE, Fomon SJ. Strategies for the prevention of iron deficiency: iron in infant formulas and baby foods. Nutr Rev 1996; 54 (11): 348-54 
7. ANEXOS 
Anexo 1 
1- desgostei muitissimo

2- desgostei ligeiramente

3- indiferente

4- gostei ligeiramente

5- gostei muitíssimo

Nome: Idade
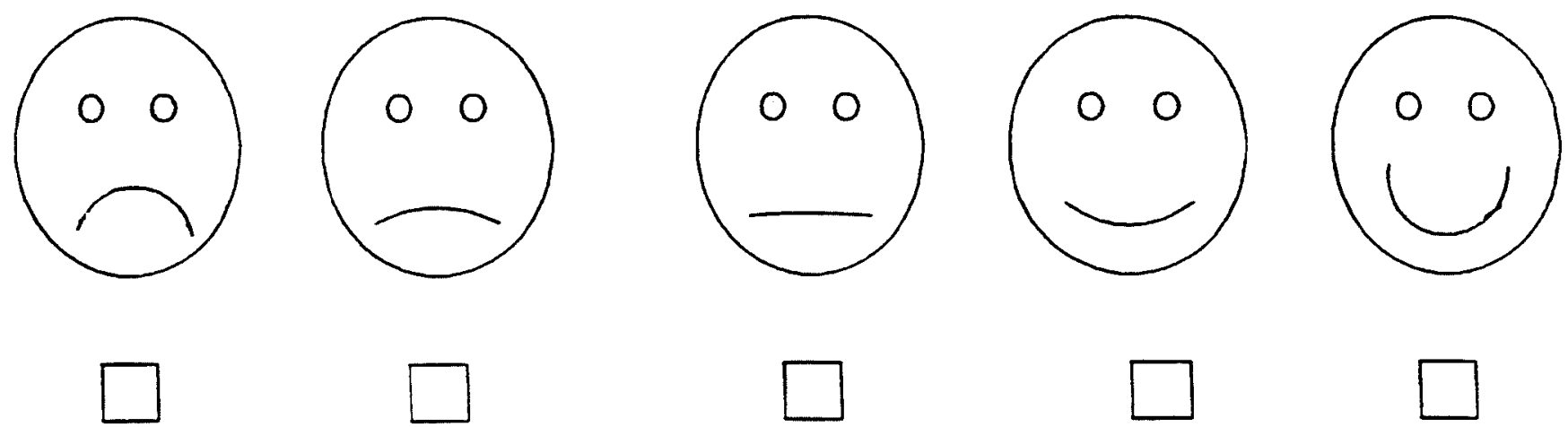

Faça um $\mathrm{X}$ dento do quadro abaixo da figura que melhor descreve sua opinião sobre esse produto 


\section{Anexo 2}




\section{Intervenção nutricional}

Os snacks obtidos por otimização da textura por Metodologia de Superfície de Resposta serão utilizados como complemento no lanche de crianças que frequentam o Centro da Juventude Paulo de Tarso (CJ) a fim de aumentar o consumo de ferro por esta população.

Para o desenvolvimento do experimento foi selecionado o Centro da Juventude Paulo de Tarso, conveniado com a Prefeitura do Município de São Paulo. O CJ tem cerca de 100 crianças e adolescentes, entre 6 e 15 anos, de ambos os sexos, que permanecem no local após o horário escolar exercendo atividade lúdicas e reforço escolar.

Cada familia foi previamente informada dos objetivos do estudo e o termo de consentimento em anexo (Anexo 3) foi ser assinado pelos pais ou responsáveis para que a criança participe da população de estudo. A intervenção proposta foi aprovado pelo Comitê de Ética da Faculdade de Saúde Pública-USP, quanto aos aspectos éticos da abordagem adotada (Anexo 4).

Para verificação dos índices nutricionais será realizada pesagem direta das refeições oferecidas com posterior cálculo per capita. Será realizada ainda avaliação antropométrica, peso e altura. A avaliação do consumo através de pesagem tem por objetivo avaliar o consumo médio de nutrientes pela população estudada fornecendo uma previsão da adequação da dieta.

Para verificação dos índices bioquímicos serão determinados os niveis sangüíneos de hemoglobina (DeMAEYER et al 1989). 
Amostras de sangue serão colhidas no inicio do experimento, antes da administração dos snacks e novamente ao final do experimento, após a ingestão dos snacks para verificar a prevalência de anemia na população estudada e sua possivel recuperação (HEUVEL et al 1997). Para dosagem de hemoglobina será utilizado um pequeno volume sangüíneo, aproximadamente $20 \mu \mathrm{l}$, para uma maior confiabilidade dos resultados. Para tal, será utilizado fotômetro portátil (HemoCue) para leitura das amostras sangüineas obtidas por punção digital com lancetes descartáveis "Microtainer". No diagnóstico de anemia será adotado como nivel de corte concentrações menores que $12 \mathrm{mg} / \mathrm{dl}$ para crianças de 6 a 14 anos, segundo a Organização Mundial da Saúde (DeMAYER 1989). 
Anexo 3 


\section{TERMO DE CONSENTIMENTO}

EU,

pai ou responsável pelo menor

dou o meu consentimento para a participação do mesmo na pesquisa intitulada "Avaliação Bioquímico Nutricional de extrusados à base de misturas de milho (Zea mays L) e pulmão bovino", sob responsabilidade da pesquisador José Alfredo Gomes Arêas e a aluna de Doutorado Raquel de Andrade Cardoso Santiago. Estou sabendo que a criança vai fazer dois exames de sangue, no início e no final do trabalho e comer "snack"(salgadinho) durante dois meses. Os dados obtidos serão mantidos em sigilo, ao mesmo tempo foi esclarecido que sou livre para aceitar ou não a participação da minha criança nesta pesquisa e também, caso aceite, tenho liberdade para desistir a hora que quiser.

Ciente: 
Anexo 4 
UNIVERSIDADE DE SÃO PAULO

FACULDADE DE SAÚDE PÚBLICA

COMITÉ DE ÉTICA EM PESQUISA DA FSP/USP - COEP

Av. Dr. Amaldo, 715 - CEP 01246-904 - São Paulo - Brasil

Telefones: (55-11) $30667742-\operatorname{fax}(55-11) 30647314$

Or.COEP/109/98

18 de novembro de 1998

Pelo presente, informo que o Comitê de Ética cm Pesquisa, aprovou, en sua 9.198 Scssão Ordinária realizäta em 17.11.98. de acordo com os requisitos da Resolução CNS/196/96, o Projeto de Pesquisa "NUTRIÇÃo E SAÚdE: UMA ABORDAGEM INTEGRADA PARA A AVALIAÇÃO NUTRICIONAL, DESENVOLVIMENTO DE ALIMENTOS PARA FINS ESPECLAIS E INTERVENCCÃO NUTRICIONAL", aprescntado pelo pesquisador José Alfredo Gomes Areas.

Atenciosamente.

Prof.Dr. Paulo An fnipe Carvalho Fortes

Vice-Coordenador do Comitede fu ca em Pesquisa da PSP-COEP 
Anexo 5 
Derivadas da equação do experimento $E_{6}$, em realação às variáveis $x_{1}$ (umidade), $x_{2}$ (temperatura) e $x_{3}$ (rotação da rosca)

$$
\begin{aligned}
& \frac{\partial \hat{y}}{\partial x_{1}}=-0,20 \neq 0 \\
& \frac{\partial \hat{y}}{\partial x_{2}}=-0,20-0,25 x_{3}=0 \\
& \frac{\partial \hat{y}}{\partial x_{3}}=-0,16-0,52 x_{3}-0,25 x_{2}=0
\end{aligned}
$$

Dessas equações:

$$
\begin{aligned}
& x_{2}=1,04 \\
& x_{3}=-0,8
\end{aligned}
$$

